\title{
ŻYĆ MOCĄ DUCHA BOŻEGO W KOŚCIELE
}

\section{TO BE LIVING WITH THE POWER OF GOD'S SPIRIT IN THE CHURCH}

Our life as the Christen in the community ecclesial is the announcement about God, which gives the people the gifts of love, freedom, friendship and truth. Through the forgiveness and the activity of the salvation of God, love and friendship in man's life makes the human world more divine. This Jesus accents in His proclamation about the kingdom divine, specially in the parables, where He presents the model of the world based on love, hope, faith and freedom as the world of deeds based on God. Therefore, with the power of God's Spirit, man has to make his life based on the norm of divine, because only in God, with God and through God exists for man the possibility to life now on earth, and afterwards in the future in heaven. In this situation, the answer of the man of faith has to be the motivation to take up the "deed" of the renovation of self-life and the imitation of God. This constitutes as the Christian thought that the central point of the theological interpretation of the value of salvation is realized - hic et nun - as the historical and existential value of the human life in the right of the kingdom divine. The proclamation of Jesus about the "new life", presents to man the values of the divine existence in the spiritual of the Church. On one hand, it is the gift of freedom and the liberation from sin, where the love of God is absolutely necessary. On the other hand, the "new life" opens for man the space of liberty of life, where God forgives the human offences and the sins, both past and present. Well now the resume of the call to imitate God is the acceptance of the divine gift, which changes the man himself, and all the people, who seek the help and good councils to live the norm divine. These witnesses in the human mentality the consciousness of the 
existence based on the divine laws, which have in themselves the dimension eschatological.

Key words: life, faith, God, man, Church, salvation.

„Niech zstąpi Duch Twój i odnowi oblicze ziemi”. Słowa św. Jana Pawła II wypowiedziane na Placu Zwycięstwa w Warszawie w 1979 roku, podczas jego pierwszej pielgrzymki do Ojczyzny, nie ucichly. Nadal są niesione echem w progi świątyń, na pielgrzymkowe szlaki, w ciszę zasłuchanych „nawracających się”. Coś w tym jest , że on „coś” już widział, że może to zaistnieć. Pontyfikat Papieża-Polaka doceniamy już z perspektywy tego, co zapisano w kadrach fotograficznej pamięci historycznych kronik, na szpaltach gazet i w albumach. Nie jest to „martwa litera” wypowiedzi jego nauki, jego przesłania do świata, jego pielgrzymowania po wszystkich kontynentach ziemi. W 100. rocznicę jego urodzin i w 15 lat po jego śmierci, warto zatrzymać się nad jego wizją świata „zszywanego” nicią Bożej Miłości, Duchem Świętym. On „wiedział” i „widział” na horyzoncie naszych dziejów w nowym tysiącleciu chrześcijaństwa, że nie będzie „łatwo" sprostać nowym wyzwaniom. Nie wątpił jednak w asystencję Ducha Świętego, w możliwości Kościoła w zaradzeniu temu wszystkiemu, co zaskoczy świat. Odczuwamy jego wstawiennictwo z nieba, bo to, co „wyrabia” świat, może nas niepokoić i przerażać. Nowe ideologie infekują ludzkie społeczności wyimaginowaną i niszczącą godność ludzką „prototypami” orientacji wszelkiego rodzaju ${ }^{1}$. To dowód, że może zagubił się świat na "górskich szlakach” prowadzących na szczyty, które wmawia się, że są, ale ich nie ma. Pozorują ich istnienie, zwodząc, że są chwilowe w chmurach i we mgle. Gdy przychodzi powiew Ducha Świętego, to okazuje się, że to nie ten szlak, nie ta droga, nie ten kierunek, nie ta pora. Ale niestety, minął czas i włożony wysiłek wspinaczki na topniejące lodowce. Dociera do nas coraz bardziej słyszalny głos; „Przyjdź Duchu Święty, [...] przyjdź w swojej mocy i sile”, wypowiadany przez wielu mijających nas na codziennych drogach życiowych zmagań.

Powoli dociera do naszej świadomości to, co ponownie nas sprowadza do Kościoła. Zaserwowano nam Kościół z mediów, a nie z eklezjalnej wspólnoty². Pustoszejące świątynie, oziębłość religijna, arogancja wobec wierzących i praktykujących chrześcijan, przerodziła się w „zalegalizowanie” światopoglądu „Bez Boga do każdego proga”. Wyobcowanie i matowe barwy ludzkiej egzystencji, depczący nam po piętach koronawirus, obnażają naszą słabą odporność

1 Por. J. Guzowski, Paweł VI o budowaniu cywilizacji miłości, „Studia Elbląskie” XXI (2020), s. 309-322.

2 Por. A. Lepa, Świat manipulacji, Częstochowa 2011, s. 199-209. 
psychiczną, biologiczną, duchową ${ }^{3}$. Zawalił się nam nasz „domek z kart” przy podmuchu reklam, medialnych nowinek. Umilkły stadionowe hasła: „Chleba i igrzysk”. Można by negacją dochodzić swych racji w przeforsowaniu projektów na rewitalizację Kościoła, który „gdzieś” jakby odpływa. Kto się nie zabrał na jego pokład, został na brzegu. Widząc oddalających się, jest nuta żalu spóźnienia się, brak niezdecydowania, posiadanie małej wiary. Oni wypłynęli na głębię, tam, gdzie Jezus swoim uczniom polecił wypłynąć, by tam dopiero zarzucili sieci. I rzeczywiście dokonali wielkiego połowu. Czy uda się rybakom Kościoła dokonać tego i tym razem? Zagadka to tylko na ludzką inteligencję. „Dla Boga bowiem nie ma nic niemożliwego" (Łk 1, 37). To usłyszała Maryja od Archanioła Gabriela. Jej nieplanowane nigdy spotkanie z Bożym posłańcem otworzyło Ją w jednym momencie na to, co dopiero oznajmił Jej Gabriel: „Duch Święty zstąpi na Ciebie i moc Najwyższego osłoni Cię" (Łk 1, 35). Czy otwieramy się i my także na to, jakby „zstąpienie Ducha Świętego” chcącego nam dać swej mocy? Zależy to od uchylenia drzwi naszych serc i umysłów, by mogło wpaść na naszą zroszoną łzami rolę Boże światło potrzebne do wzrostu zasianych w nas darów Bożych. W refleksji teologicznej warto odnieść się do niektórych tekstów biblijnych, zaczerpniętych z Liturgii Słowa Okresu Wielkanocnego, by opierając się na nich, odczytać to, co przygotował nam zamysł Boży.

\section{W blasku Zmartwychwstałego Jezusa}

Po Zmartwychwstaniu Jezusa zaistniała dla Apostołów, i nie tylko dla nich, ale i dla wcześniej słuchających Go tłumów, jak i Jego przeciwników, nowa rzeczywistość. Pojawiło się to, czego nie mogli zrozumieć! Najbardziej w zakłopotanie wprowadził Zmartwychwstały Chrystus gremium Sanhedrynu. Bo zaczynają oni coś z tego powoli kojarzyć, ale i czegoś się obawiać! Przecież to oni skazali Jezusa na krzyżową Mękę i wieść o Jego Zmartwychwstaniu stawia ich w lęku o wydany na Chrystusa wyrok, że mógłby być to rzeczywiście Bóg!!! Ten, Któremu mieli służyć, Którego czcili w świątyni i synagogach. Uświadamiają sobie, że tu mają do czynienia z mocą Bożą4.

Dla uczniów Jezusa to także doświadczenie składającego się „domina” ich planów, co do wizji królestwa Bożego. Nie tak miało to być, jak chcieliby, by się stało. Dwaj uczniowie udają się do Emaus. W obawie przed prześladowaniem opuszczają Jerozolimę i pragną tylko bezpiecznie się ukryć. Na razie zamierzają przeczekać zaistniałą sytuację, by następnie widząc, co się dzieje, podjąć dalsze swoje decyzje. Idąc drogą byli zapewne bardzo czujni na jakiekolwiek spotkanie

3 Por. A. Kot, Emergenza sanitaria/Covid-19/. Una sfida per la società civile e pastorale ecclesiale, „Studia Elbląskie” XXI (2020), s. 335-353.

4 Por. V. Messori, Il a souffert sous Ponce Pilate, Paris 2002, s. 181-190. 
się z kimś obcym. Czuli z pewnością na sobie już „wzrok” poszukujących ich i wytężali „słuch” na każdy odgłos pochodzący z oddali. Zarazem przenikała ich tajemnica, że nie mogli zrozumieć, co znaczy „zmartwychwstać”, jak oznajmily im niewiasty będące o świcie przy grobie Mistrza ${ }^{5}$. Widzieli już wychodzącego Łazarza z grobu, wskrzeszenie córki Jaira czy młodzieńca z Nain, ale że Jezus sam wyszedł z grobu, mimo zatoczonego kamienia, przekraczało ich wyobraźnię. Nieoczekiwanie, mimo wytężonej uwagi i obaw o siebie, niepostrzeżenie zbliżł się, jakby z zaskoczenia, ktoś Nieznajomy. I jego wprost skierowane do nich pytanie : „O czym to rozmawiacie?” wprawia ich w osłupienie, mówią: „Ty jesteś chyba jedynym, który nie wie, co się wydarzyło w Jerozolimie z Jezusem". Uczniowie wyjaśniają zaistniałe zdarzenie jako świadkowie i obserwatorzy tego, co się działo na scenie Jerozolimy. Nie rozpoznali Tego, Kto był główną postacią dokonanego zaledwie parę dni temu wydarzenia zbawczego. A przecież patrzyli na to swymi oczyma. Teraz ich oczy, jak pisze Ewangelista, „były niejako na uwięzi" (Łk 24, 16). Byli ślepi. Widzieli, a nie widzieli, słyszeli Jezusa, ale Go nie słyszeli. To, co mówi Apostołom spotkany Nieznajomy wyjaśniając Pisma, ma swoje odniesienie do tego, co oni już „co nieco” od swego Mistrza słyszeli. Coś im jakby może „świtało”, jednak nie na tym koncentrowała się ich uwaga. Z tego to powodu postawi im później Jezus zarzut, że nie zrozumieli tego, co On im mówił, czego chciał nauczyć, co im w cudach uzdrowień pokazał. Obecnie byli rozkojarzeni, zagubieni w lęku o dalszy swój los. Zniknęła wizja widzenia i odczuwania bliskości Mistrza, nie rozpoznali Jego głosu, Jego sylwetki, Jego gestów i charakterystycznych dla Niego zachowań. A to zapewne pozostało w Jezusie niezmienne. Zasunięty kamień na grobie Jezusa odizolował ich od Niego. Można odkryć w uczniach zdążających do Emaus analogię i do naszej postawy. Jaki jest dla nas Jezus przed swoją Męką? Jaki jest dla nas w dźwiganiu krzyża i w swoim konaniu? Jak możemy Go rozpoznać po Jego Zmartwychwstaniu? Poszliśmy za Nim, jak nawoływał, wiernie za Nim, jak owce z Jego stada. A jeśli się zagubiliśmy, to On nas szukał i myślimy, że będzie zawsze nas szukał, bo innych szuka, to i nas nie zostawi samych sobie w potrzebie. On był przed swoją Męką czytelnym obrazem dobrego Pasterza, który wie, gdzie idzie i dokąd powierzonych sobie prowadzi (por. Mk 6, 34).

Jezus po swoim Zmartwychwstaniu idzie do swoich uczniów, gdyż potrzebują umocnienia ${ }^{6}$. Świadectwo Marii Magdaleny czy uczniów powracających z Emaus nie przekonuje Apostołów. Oni byli świadkami Męki i Śmierci Mistrza i w to wierzą. Ale Jego Zmartwychwstanie „nie mieści im się w głowie”. To wykracza poza ich horyzont wyobraźni. Usłyszane zeznania widzących już

\footnotetext{
5 Por. B. Rey, Jésus-Christ chemin de notre foi, Paris 1991, s. 64-66.

$6 \quad$ Por. J. Ratzinger, Voici quel est notre Dieu, Paris 2001, s. 158-172.
} 
Zmartwychwstałego jednak zastanawiają ich, bo to, jak o tym mówią i jak się zachowują, ma inne objawy, aniżeli byli oni znani im ze swego wcześniejszego sposobu bycia. Nie dało się nie odkryć w ich opowiadaniach radości, entuzjazmu, odzyskanej nadziei, euforii czy zachwytu i podniesionego zapewne głosu oznajmiającego „szybko jakby jednym tchnieniem” te zdarzenia. A jednak zachowują się Apostołowie tak, jakby „grali na przetrzymanie”, na wyjaśnienie „zagadki” braku ciała Jezusa w grobie. To, że w tym czasie wątpili nie eliminowało ich $z$ odgruzowywania wiary w Zmartwychwstanie Mistrza? Cała budowla ich marzeń o „politycznym panowaniu Mesjasza” zawaliła się i teraz potrzeba było dokonać rachunku strat i możliwości odrestaurowania tego, co się da odbudować w swym oryginale, a co trzeba „dorobić”. Te dni Męki Jezusa i Jego dni po Zmartwychwstaniu pokazują pewne zachwianie się i naszego poglądu na życie z Bogiem. Póki jest dobrze i życie się toczy normalnymi torami tradycyjnej pobożności, bez nadmiernej destabilizacji, jest dla nas zadowalającym i sprzyjającym harmonogramem codziennej egzystencji. Ale, kiedy odczuwa się „trzęsienie ziemi”, wówczas dostrzega się, że nie stoimy mocno na solidnym gruncie. I to dobrze wiemy, jeśli poluzuje się nasza szczera więź z Bogiem, z Jego Dekalogiem, wówczas zacznie się nasze podążanie na intuicję, z rozmagnesowanym kompasem po poboczach i bezdrożach pseudochrześcijańskiego życia, co nie zawsze może mieć cokolwiek wspólnego z tym, co nas do Kościoła winno wprowadzać. Częściej może się z niego wyprowadzamy? Chociaż z doświadczenia wiemy, że zmęczeni, pokaleczeni, okradzeni, utrudzeni i znużeni pokusami świata, gdy już nas nic nie cieszy, wracamy do Kościoła, stukając nieraz i późną nocą, by nam otworzono wrota do „szpitala duszy”. I wtedy nawet, mimo późnej pory, pełni zdziwienia przekonamy się, że jednak i w ciemnościach swego zadymionego sumienia potrafimy widzieć! Szanujmy te oczy wiary! One się jeszcze nam może wiele razy przydadzą. To się może i nam przydarzyć, że Jezusa nie rozpoznamy. Tak, jak Jego uczniowie w drodze do Emaus nie spostrzegli, że szedł z nimi ich Mistrz! Rozmawiali z Nieznajomym. Jak? Z „żywym” Jezusem mówili o „zmarłym” Jezusie! ${ }^{8}$ Ale taki był ich nadal krajobraz życia i zachwianej wiary. Horyzont Golgoty i złożony Jezus w grobie. Poznali Go dopiero po łamaniu chleba, czyli spożywaniu posiłku! Zasłyszane słowa błogosławieństwa nad chlebem podczas wieczerzy otworzyły im uszy i oczy na Jezusową tak bliską obecność 9 . Mogli teraz „widzieć życie”, nawet „dotykać życie”, czego świadkiem był „niewierny” Tomasz. Dla uczniów

7 Por. Franciszek, Posynodalna adhortacja apostolska „Christus vivit” do mtodych i całego Ludu Bożego, Poznań 2019, s. 76-78.

8 Por. B. Rey, Viure avant et après la mort, Paris 2001, s. 19n.

9 Por. Jan Paweł II, Wierzę w Kościót, Città del Vaticano 1996, s. 130-133. 
udających się do Emaus nie przechodzi nawet przez myśl, że to, co Chrystus zapowiadał, mogło w Nim i przez Niego zaistnieć ${ }^{10}$. My także mamy ograniczony zasięg widzenia Jezusa i dzisiaj w naszej codzienności. I tacy możemy pozostać bardzo długo, dopóki nie ruszymy w drogę ucieczki, jak uczniowie początkowo zmierzający do Emaus, dopóki nie uciekniemy od swego kalectwa życia sparaliżowanego grzechem, by spotkać gdzieś na drodze wiary Jezusa, który - jak się okaże - sam nas odnajdzie i poda lek uzdrowienia duszy po dobrej diagnozie medycznej kuracji serca. Nawiedzajmy świątynie i wchodźmy do Wieczernika na Ostatnią Wieczerzę - Eucharystię, bo to jest takie miejsce, gdzie możemy przyjąć Boga w Komunii św. Choć może czujemy się niegodni Go przyjmować, to jednak Go potrzebujemy. A może potrzeba nam czegoś bardziej doświadczyć, by rozpoznać w sobie pragnienie Boga? Może potrzeba "niemych rekolekcji” $z$ wnętrza grobu Jezusa, może trzeba do niego wejść i rozejrzeć się dając sobie odpowiedź: „Czego tam szukam”! Innej drogi wyjścia z grobu Jezusa nie ma oprócz tej, którą się weszło! Po spotkaniu z Jezusem, uczniowie jeszcze „w tej samej godzinie wybrali się i wrócili do Jerozolimy".

„On stanął pośród nich i rzekł do nich: Pokój wam!” (Łk 24, 36). Przelękniętych widzeniem „ducha Jezusa” Apostołów ogarnia lęk. Odczuwają w sobie obawę, że teraz to bardzo wnikliwie może ich Jezus „prześwietlić” z ich motywacji i postawy zachowania się w czasie od Jego pojmania aż do ukrzyżowania Go. Niepokój wprawił ich w zakłopotanie, że nic nie da się już przed Nim ukryć. Nie mają argumentów na wytłumaczenie się przed Nim z tego, co zrobili, a raczej, czego nie zrobili, by Go bronić, jak Mu obiecywali. Być może nurtowała ich i „podstępna” myśl, czy nie byłoby lepiej, aby Go teraz nie spotkać? Może później, jak czas zaleczy rany, mogliby się Mu „przypomnieć” ze swej „nieudolności” i usprawiedliwić się? Jednak Jezus dekonspiruje ich „planowanie” i wchodzi do Wieczernika mimo drzwi zamkniętych. Dla Chrystusa nie ma zamkniętych odrzwi, których by nie przenikał ze swoją miłością ${ }^{11}$. Nawet zamknięcie się w sobie z własnymi myślami nie stanowi bariery nie do przekroczenia przez Boga. On wnika we wnętrze ludzkiego życia i prześwietla jak promienie rentgenowskie, by ukazać nam to, co jest niepożądaną „infekcją” w naszym organizmie. Apostołowie w Wieczerniku w obawie przed prześladowaniem zaryglowali się i czekali na bieg wydarzeń. Ten czas oczekiwania na to, co ma być, niepokoił ich i nie nastrajał do bycia odważnym. Przyjście Jezusa do nich ze słowami : „Pokój wam” zaskakuje ich i wprawia w zakłopotanie, ale i uspokaja. Tego pokoju ducha pragnęli i On im go daje. „Czemu jesteście zmieszani i dlaczego wątpliwości budzą się w waszych sercach” (J 24, 38). Gdy

\footnotetext{
10 Por. Franciszek, Prawda jest spotkaniem, Kraków 2019, s. 65-67.

11 Por. B. Rey, La Discretion de Dieu, Paris 1997, s. 37n.
} 
mówi Jezus o ich zatrwożonych sercach, odkrywają prawdę, którą nie oni sami, ale On im ją wypowiedział. Tak, byli zatrwożeni i zalęknięci. To paraliżowało i ograniczało swobodę w roztropnym ich teraz działaniu. On ich rozszyfrował w mgnieniu oka! I to słyszą! Rozpoznają już Jego głos, rozumieją Jego mowę. Jeszcze bardziej „zbliżają się” do postaci Jezusa ze swym utkwionym w Nim spojrzeniu, aby dostrzec rany na Jego ciele: „Popatrzcie na moje ręce i nogi: to Ja jestem. Dotknijcie się Mnie i przekonajcie" (J 24, 39). Jeszcze bardziej popadają w osłupienie, gdy prosi ich o pożywienie, aby udowodnić im, że nie jest „zjawą”, ale że ma ciało ${ }^{12}$. To rzeczywiście ich Mistrz! Zagrał Jezus ze swoimi uczniami o wiarę w swoje Zmartwychwstanie „va-bank” i wygrał ich wiarę! Ujrzeli Go, usłyszeli Jego głos, „przekuli” swoją dotychczasową wiarę w Mistrza w nową wiarę w Jego Boskość, która ich wzmocni w chwilach podejmowanych niebawem decyzji o swoim męczeństwie za wiarę w Chrystusa. Ta poprzednia wiara okazała się jedynie przyjaźnią, braterskim zaufaniem do chwili egzaminu, kiedy to „prawdziwych przyjaciół poznaje się w biedzie”. Nie czuli się dotychczas godnymi "przyjaciółmi” Jezusa, bo nie znali prawdy ani o Mistrzu, ani o sobie samych. Teraz, po spotkaniu ze Zmartwychwstałym i rozpoznaniu Go, mogli poważniej zweryfikować swoje życiowe plany względem Chrystusa. I pójdą odważnie w świat umocnieni Duchem Świętym, by głosić Jego naukę, którą słyszeli, Jego cuda, które widzieli i Jego Zmartwychwstanie, które otworzyło im oczy na moc Zbawienia wpisaną w dramat Golgoty i w Jego pusty grób ${ }^{13}$.

\section{Ponowne powolanie}

Jezus Zmartwychwstały przychodzi do swoich zagubionych uczniów w blasku dnia, o świcie. Przychodzi do nich w Galilei, gdzie żył, gdzie spędził swoją większą część życia, gdzie powołał swoich Apostołów ${ }^{14}$. Nowy początek, gdzie się wszystko zaczęło. Jezus nie czyni wyrzutów wybranym. I także ich nie wymienia na innych. On w zatroskaniu o dalszy ich los „leczy” rany ich zwątpienia. On zna psychikę ludzką, zamysły serca, ich możliwości. Odeszli oni od krzyża, który ich „przerósł”. Powrócili łowić to, co przed swym powołaniem robili. Horyzont ich dalszego trwania w „szkole Jezusa” pokryty został mgłą i ulotnił się. Zapał nie wystarczył. Ale i to, czym teraz się zajęli, także ich rozczarowuje. Całą noc łowili i nic nie złowili. A na brzegu czekali kupcy i ludzie na targu, by nabyć od nich złowione nocą ryby. Zastanawiają się, że może po trzech latach nieobecności na rybackiej łodzi w swoim zawodzie wyszli z wprawy, ale ufają,

12 Por. J. Ratzinger - Benoît XVI, Jésus de Nazareth. Del entrèe à Jèrusalem à la Rèsurrection, Libraîrie éditrice vaticane 2011, s. 304n.

13 Por. B. Rey, Marcher vers Toi, mon Dieu, Paris 2004, s. 72n.

14 Por. J. Ratzinger, Voici quel est notre Dieu..., s. 236-238. 
że w następne dni, czy tygodnie poprawi się to i będą sprawniejsi w połowach ryb. Dlatego sceneria wydarzenia: „ciemnej nocy” i „smutek” z nieudanego połowu przygnębia ich i nie dodaje im entuzjazmu. Jednak Jezus trafia w sedno ich oczekiwań w tej danej chwili. On daje im „nowy poranek” i „nowy początek”, nową nadzieję i optymizm. „Zarzućcie sieć po prawej stronie łodzi!” (J 21, 6). Mimo już odczuwalnego zmęczenia zarzucają jeszcze raz sieć w głębię jeziora. I nagle widzą, że sieć napełniła się rybami. Mimo że początkowo nie rozpoznali w Tym, który nakazał im rzucić sieci Jezusa, to po obfitym połowie już nie wątpią, że to jest ich Mistrz ${ }^{15}$. W zachwycie Piotr zostawia cały połów w niewyciągniętych sieciach i rzuca się w wodę, by dopłynąć jak najszybciej do stojącego na brzegu i wpatrzonego w ich połów Jezusa. Chociaż poszedł łowić ryby, teraz to go już nie interesuje. Nie tym zaczyna żyć. Rozpoznając Chrystusa i pozostali uczniowie pośpiesznie dobijają do brzegu na spotkanie z Mistrzem. Czy i my także śpieszymy się na spotkanie z Jezusem? Czy dajemy Mu się rozpoznać i poprzez modlitwę odżywa w nas pragnienie przebywania w Jego obecności? Zmartwychwstanie to nowy początek tego, co już wcześniej sprawiło, że zasłuchani byliśmy w Jezusa, że zanurzeni w Jego piękną miłość fascynowało nas bycie Jego uczniem ${ }^{16}$. I to nadal w nas trwa jako tęsknota, że chcemy często zaczynać od nowa, gdy po grzechu z podciętymi skrzydłami tracimy stabilność prawego i dobrego lotu życia. Ilekroć zrywamy z grzechem doświadczamy już zmartwychwstania i wyjścia z tonącej łodzi na stabilny grunt brzegu. Na ile zawierzamy Bogu, na ile $\mathrm{Mu}$ się poddajemy w hartowaniu naszego charakteru i chrześcijańskiej postawy? Na ile wierzę w to, co mówi mi Chrystus? On nadal stoi na brzegu i wypatruje nas niejednokrotnie mozolnie zarzucających sieci w nurt wód, aby coś z życia i w życiu ułowić. Może potrzeba częściej podnosić głowę i odwracać skupiony wzrok jedynie na sieciach, aby spoglądać na brzeg, czy nie ma tam Jezusa, który podpowie, gdzie jest ławica ryb.

Chrystus stoi na brzegu naszego życia i mówi: „Dzieci, czy macie co na posiłek? (J 21, 5). Jak On się troszczy o pokarm w naszym życiu! Nie pyta, czy to jest nasza łódź, czy sieci są naprawione, czy jesteśmy już „urobieni” całonocną pracą przy nieudanym połowie, bo On to widzi i wie. Ale czy jesteśmy głodni! Czy nie pracujemy w głodzie i w zwątpieniu w dalszą bezużyteczność naszych wysiłków i zmagań! Szczera odpowiedź uczniów na pytanie Jezusa o posiłek otwiera nasze oczy na potrzebę widzenia w Eucharystii prawdziwego pożywienia dla ludzkiej duszy ${ }^{17}$. Z jej mocą nie zabraknie nam sił, by wiele razy wypłynąć

15 Por. J. Neumann, Kościót trzeciego tysiąclecia, Warszawa 2006, s. 242-245.

16 Por. Franciszek, Prawda jest spotkaniem..., s. 111-113.

17 Por. J. Neumann, Kościót trzeciego tysiąclecia..., s. 192-201. 
na głębię życia i daleko zarzucić sieci na połów ludzkich serc, zasłuchać się w katalog ludzkich trosk i podjąć próbę ich zaradzeniu.

„Szymonie, synu Jana, czy miłujesz Mnie?” (J 21, 15). Pytanie Jezusa wypowiedziane do Piotra spotyka się z odpowiedzią jakby „wymigującą się”: „Tak Panie, Ty wiesz, że cię kocham”. Gdy porównamy słowa „miłujesz Mnie” i „kocham Cię”, to w przekładzie greckim znajdziemy znaczącą różnicę sensu w podtekście użycia tych słów przez Jezusa i przez Piotra. Chrystus pyta Piotra

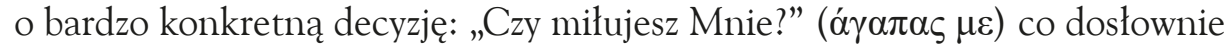
w języku greckim wyraża: „Czy darzysz Mnie tak wielką miłością wpisaną w cenę śmierci, że pójdziesz za Mnie nawet na śmierć"? A Piotr odpowiada za pierwszym i drugim razem zwrotem: „Tak Panie, Ty wiesz, że cię kocham”. „Kocham Cię" $(\varphi \curlywedge \lambda \omega \sigma \varepsilon)$ ma znaczenie w dosłownym tłumaczeniu z greki jako „lubię Cię”. Różnica słów „miłować” i „lubić” jest zatem diametralnie odmienna. „Lubić” nie wymagało od strony zobowiązującej się do dania czegoś w zastaw za kogoś czy wykupu. Kogoś darzyło się jedynie sympatią, a to nie wymagało ofiary życia w zamian za złożoną mu przysięgę, a raczej w miarę możliwości i dyspozycyjności czasowe lub w pewnej wartości materialnej jedynie poręczenie. Było to tylko wyrazem szacunku, uznania, godności tej osoby, dobrych relacji, przyjacielskiego oddania. Ale nic poza tym. „Miłować” było wyżej cenionym pojęciem od „lubić” i nieczęsto je składano jako przyrzeczenie czy przysięgę. Jezus używa określenia „miłować”, zaś Piotr odpowiada słowem: „lubię Cię”. Za trzecim razem Jezus pyta używając słowa, jakim posługuje się Piotr: „Czy lubisz Mnie?” Dlaczego Piotr tak się bronił przed „umiłowaniem Mistrza” aż do śmierci? To, co już go spotkało ze składanych przysiąg, to nie rozróżniał, co i kiedy powiedział lub czego nie wyznał. Raz przysięgał, że życie odda za Mistrza, potem się Go zaparł: „Nie znam Go”. Innym razem zwątpil, przypuszczając, że to może być jakaś zjawa na jeziorze, a nie Mistrz. Zawirował Piotrowi świat w braku jednomyślności co do bycia uczciwym względem siebie. Potrzebował czasu do uporządkowania swojego świata, a tu bieg wydarzeń przyspieszał i nie nadążał on już za podejmowaniem coraz to nowych decyzji we właściwym ustosunkowaniu się do bieżących spraw. W tym, co Piotr słyszy, zaskakuje go „zmiana” zawodu. Było on cały czas rybakiem i znał się na rybołówstwie. Mówił mu już Jezus, że „ludzi będzie łowił”, gdy go powołał na Apostoła. Teraz ma propozycję, by był pasterzem ${ }^{18}$. Piotr widział pasterzy i wielu zapewne też znał. Ale rzemiosło pasterskie znał tylko $z$ teorii. Nie miał nigdy swej trzody, nie znał się na wypasie owczego stada, doboru najemników, nie posiadał wiedzy na temat wyszukiwania dobrych pastwisk, a w razie zagrożenia musiałby sobą bronić owiec przed dzikimi zwierzętami czy złodziejami. Jego skojarzenia były

18 Por. Jan Paweł II, Wierzę w Kościót..., s. 219-223. 
jeszcze zabarykadowane w ramach „ziemskiego pasterzowania” bez jeszcze daleko idącej myśli „duszpasterzowania”. Jednak z tego dialogu, jakby się wydawało, że bardzo ubogiego w słowa, polegającego jedynie na powtarzaniu tych samych pytań i dawaniu tych samych odpowiedzi, dostrzec można „coś” z dzieła stwarzania świata. „Coś” Jezus stwarza w Piotrze, co ma zamysł Boży i polega na zapamiętaniu tego, co się słyszało i co się odpowiedziało. W stworzeniu świata Bóg sześciokrotnie „widział, że to, co stworzył, było bardzo dobre”. W tym, co Chrystus zleca Piotrowi zostaje zapisane dużymi literami jako „miłować” lub „lubić”. Jak to Piotr rozdysponuje podejmując decyzję w danej sytuacji o losie powierzonych jego opiece „duszpasterskiej”, to już będzie jego wola wypełniona z odpowiedzialnością za wydane wskazania. Zapewne z biegiem czasu Piotr ustabilizuje „ogrom” powierzonych mu przez Mistrza obowiązków w dziele troski o Kościół, co z pomocą Jezusa wykona Piotr bardzo dobrze i po Bożemu ${ }^{19}$. „Panie, a co z tym będzie?” (J 21 20). Pytanie Piotra do Jezusa o umiłowanego ucznia Jana. Po otrzymaniu od Jezusa prymatu w kolegium apostolskim, Piotr już wypełnia powierzone pierwsze zadanie z zakresu duszpasterzowania w rodzącym się Kościele. Zatroskany o los najmłodszego z grona Apostołów pyta Mistrza: „A co z tym będzie?”. Dobrze, że Piotr pyta. To oznacza, że będzie się Boga pytał, gdy stanie w sytuacji podejmowania ważnych decyzji dotyczących życia innych. To i nas przysposabia do postawy człowieka pytającego i zarazem też słuchającego. Pytać Boga! I słuchać Boga! „Słuchaj Jezu, jak Cię błaga lud, słuchaj, słuchaj, uczyń z nami cud. Przemień o Jezu smutny ten los, o Jezu pociesz nas". Ta pieśń niesie echo wielu wezwań i próśb zanoszonych już przez liczne pokolenia do nieba z oczekiwaniem na Bożą pomoc. I Bóg je wysłuchał, skoro dokonała się w sercach wielu „przemiana” losu. „A co z tym będzie?”. Pytanie Piotra z kart Ewangelii ma swoje „przełożenie” na zatroskanie się i o nas. A co z nami będzie? A co będzie ze mną? To może nas niepokoić, gdyż wydarzenia i okoliczności codziennego życia zaskakują i stwarzają trudności. Są też w naszym życiu chwile wręcz niespodziewane i „urocze”, które w jednej chwili przemieniają zadumę i bezradność w euforię i zachwyt z powodu nieprzewidzianego „rozwiązania” sprawy. To też ma swoje odniesienie do całościowego patrzenia na modelowanie się naszego życia „pod batutą” wiary ${ }^{20}$. Są dylematy i niezrozumiałe kwestie w układaniu życia po myśli ludzkiej i Bożej. Jednak mądre przysłowie ludowe: „Bez Boga ani do proga” sugeruje nam, dzisiaj poszukującym dobrej nawigacji w marszu przez różnorodne drogi życia, żeby nie zapomnieć o wpisaniu w wyszukiwarkę sumienia hasła: „Bóg”. Tym, czym żyjemy, co nas otacza, co „los nam zgotuje”, czemu potrafimy sprostać,

19 Tamże, s. 224-227.

20 Por. J. Tischner, Myślenie wedlug wartości, Kraków 1982, s. 481-487. 
a co nas przerośnie i zatrzyma, co zdominuje i doda animuszu, a co nas spowolni i w pustkę wrzuci, inspiruje nas do „wchodzenia” na coraz to wyższe szczyty zblizające nas do Boga w niebie. Asekuruje nas „lina łaski”, tak jak wspinającego się na szczyt po urwistej skale zabezpiecza uprząż, liny i haki. Są pewne wyzwania, które nie dają nam czasu na przeanalizowanie i wielokrotne zastanowienie się nad podjęciem odpowiedniej decyzji. Chociaż nieraz powaga sprawy wymaga rozłożenia w czasie tego, co już w życiu czyniliśmy i co się zrobiło, to ma już swój zapis w sumieniu. I według odczuć prawego i szczerego sumienia podejmuje się nieraz natychmiastowe działanie. W tym poszukiwaniu racji i argumentów za jak najlepszym działaniem pomocą była i jest wiara ${ }^{21}$. Ona zawsze podprowadza do Chrystusa i dodaje odwagi, by zapytać Go: „Co mam czynić, aby osiągnąć życie wieczne?" (Mt 19, 16). Tak zapytał Go bogaty młodzieniec. Jezus pochwalił go, że chce coś jeszcze w swoim dążeniu do świętości zmienić, poprawić, „zresetować”, dodać coś nowego z katalogu „promocji”. Chrystus pozwala mu się „wytłumaczyć”. Nawet wobec wszystkich otaczających Go pochwala młodzieńca, że przestrzega Dekalogu, co nie jest lekkim „męstwem” "22. Zachęca go dodatkowo, by poszedł do domu, rozdał swój majątek ubogim i wolny już od balastu zamożności powrócił i wtedy mu pozwoli chodzić z sobą. Młodzieniec odchodzi, ale już nie wraca. Nie zdecydował się na wyprzedaż majątku i stanie się „mniej zamożnym”. Odchodzi zasmucony. Może zagalopował się w stawianiu pytań Jezusowi i postawił ich za wiele? Ale czy my nie stawiamy Bogu też zbyt wiele pytań, na które odpowiedzi pomogłyby nam w podjęciu, odwlekanych zwykle na później, naszych decyzji i finalnych rozstrzygnięć? A może stawiamy za mało pytań, bo zbyt literacko „kombinujemy” w złożeniu „zamówień” na dobre życie? Może jak Piotr winniśmy mieć szablon konkretnego pytania i stanowczej odpowiedzi: „A co z tym będzie?”

\section{„Narodzenie się z Ducha Świętego”}

Słowa Jezusa wypowiedziane do Nikodema, który późną nocą przychodzi do Jezusa, wprawiają w zadumę i konsternację. „Jeśli się ktoś nie narodzi powtórnie, nie może ujrzeć królestwa Bożego" (J 3, 6). Życie nadprzyrodzone, życie dane z "góry” od Boga ma inne zabarwienie i dokonuje bardzo często diametralnych zmian w egzystencji człowieka poszukującego wiary. Niejednokrotnie zdefraudowane życie ludzkie traci na wartości, jednak wiara w Boga może zostać „odnaleziona” jako cenny rekwizyt i to o wielkiej wartości jako muzealny eksponat. Warunkiem odzyskania blasku „dziecięctwa Bożego” jest

${ }_{21}$ Por. P. Coda, Ch. Hennecke, La fede, evento e promessa, Roma 2000, s. 94n.

22 Por. Z. Kijas, Czy wiesz, że modlitwa..., Katowice 2020, s. 137-150. 
„narodzenie się z wody i Ducha Świętego” (J 3, 5). Było to i jest trudnością dla każdego z nas w ogarnięciu bogactwa tajemnicy działania mocy Ducha Świętego, Bożej Miłości²3.

W porze nocy przychodzi do Jezusa Nikodem i to, co słyszy od Jezusa o narodzeniu się, jest myślową jednością z faktem narodzenia się Jezusa także nocą w grocie w otoczeniu betlejemskich pasterzy. Nikodem, dostojnik żydowski, jako jeden z członków Wysokiej Rady, pełniący rolę „pasterskiego przewodnika” w życiu religijnym Izraelitów, przychodzi do domu, gdzie przebywa Jezus. Pyta o prawdę, o nowe życie, o to, co było przedmiotem Jego posługi względem swoich rodaków ${ }^{24}$. Nie zraża się Nikodem swoją niewiedzą, gdy wypomina mu Jezus: „Ty jesteś nauczycielem Izraela, a tego nie wiesz?” (J 3, 6). Może i nam potrzeba nieraz odważnej i bezpośredniej konfrontacji z Chrystusem na temat tego, co my wiemy o życiu i o tym, co je tworzy. Wszak decydujemy w wielu sytuacjach o postawie swojej i innych, gdy wymaga tego nagła okoliczność i obowiązek uzasadnionej wiedzy. „Mówimy, co wiemy, i o tym świadczymy, cośmy widzieli" $(\mathrm{J} 3,11)$. Na ile potrafimy sami uwierzyć w to, czego dokonujemy i co jest motywem naszego działania z przekonania i poznanej prawdy? Odważne spoglądanie w zwierciadło nie zawsze „podpowie” nam, co widzimy. Zachodząca nieraz na nie para naszych „niejasnych kalkulacji” czy dwuznacznych reakcji może całkowicie rozmazać walor widoczności lustra. Wówczas nie tylko nie zobaczymy swego odbicia, ale i również tego, co się wokół nas, a zwłaszcza za nami, dzieje. „Jeśli się ktoś nie narodzi powtórnie, nie może ujrzeć królestwa Bożego” (J 3, 6). To warunkuje, że aby widzieć, trzeba „się powtórnie narodzić”. A człowiek rodzi się w tym, czym żyje, wzrasta i rozwija się w tym, co stanowi jego „gniazdo”. W głębi naszego jestestwa skrywa każdy z nas wiele pokładów cennych „minerałów”, których wydobycie czyni nas bogatymi. Dla rozeznania tego, co w nas jest, potrzeba Jezusowych wskazań, jak wydobyć z siebie to, co jest wartościowe, jak zniwelować to, co jest utrudnieniem i jak zaplanować skuteczne użytkowanie tego, co w nas Bóg stworzył jako dobre ${ }^{25}$. „Bóg widział, że było dobre” ( $\mathrm{Rdz} 1,31)$. Jeśli Bóg już zasiał w nas dobre ziarno, to naszym staraniem jest czynienie wszystkiego, by w porze zbiorów zebrać jak najobfitsze plony. One zapewnią nam pożywienie na ten czas, który nam dał Bóg do przeżycia $\mathrm{w}$ ziemskim pielgrzymowaniu. Ze swej strony daje nam Bóg w darze spadającym z nieba - wodę i ogień - Ducha Świętego, które w jedności ze sobą są w stanie „upiec” chleb eucharystyczny.

23 Por. Jan Paweł II, W Imię Trójcy Przenajświętszej, Città del Vaticano 2002, s. 145-158.

24 Por. Franciszek, Prawda jest spotkaniem..., s. 76-77.

25 Por. S. Ewertowski, Transcendencja ludzkiej osoby, [w:] Veritas Christi liberat (red.) P. Rabczyński, Olsztyn 2014, s. 187-202. 
„Jeżeli nie odejdę, Pocieszyciel nie przyjdzie do was” (J 16, 7). Podczas liturgicznego udzielania sakramentu bierzmowania śpiewany jest hymn do Ducha Świętego: „O Stworzycielu Duchu przyjdź, nawiedź dusz wiernych Tobie krąg, niebieską łaskę zesłać racz, sercom co dziełem są twych rąk”. Kimże jest zatem Duch Święty, Trzecia Osoba Trójcy Świętej? Jest On przyzywany w czynionym znaku krzyża, w modlitwie wieńczącej psalmy: Chwała Ojcu i Synowi i Duchowi Świętemu... Przekaz Mt 6, 8: „Albowiem wie Ojciec wasz, czego wam potrzeba, wpierw zanim Go poprosicie" naprowadza nas na zrozumienie prawdy o Bogu w Trójcy Świętej Jedynym. „Wie Ojciec”. Ojciec jest jako Ten, Który ma przenikliwą wiedzę o nas, wie On o nas wszystko. Również wie, czego nam potrzeba i Syn Boży i Duch Święty. „Duch Święty, gdy przyjdzie, przekona świat o grzechu, o sprawiedliwości i o sądzie" (J 16, 8). Ten, kto ma wiedzę, kto obdarza miłością musi być Osobą. Nie może być tak, by moja miłość była czyjąś miłością. Podobnie i moja wiedza jest moją wiedzą. Biblia mówi, że Ojciec ma wiedzę, Syn Boży ma wiedzę i Duch Święty ma wiedzę. „By przekonać świat o grzechu, o sprawiedliwości i o sądzie” trzeba na ten temat mieć uzasadnioną wiedzę. I tę wiedzę ma Duch Święty. Jeśli ma się swoją wolę, swoją wiedzę i swoją zdolność do działania, to jest się osobą. Duch Święty to posiada, więc jest Osobą ${ }^{26}$.

Jeden jest Bóg, jedno Jego istnienie, ale trzy Osoby Boskie ${ }^{27}$. Ponadludzkie istnienie znaczy Boskie. Jak podaje Pismo Święte - Bóg jest miłością. A miłość to atrybut Boga jak i Jego wieczność. Bez miłości i wieczności to nie jest Bóg. Czy Bóg mógłby być samotny we wszechświecie? Czy Bóg mógłby być Bogiem, jakby kogoś nie było? Miłość zakłada relację, która jest więzią z innymi osobami. Jest się zakochanym w osobie, a nie w rzeczy, w przedmiocie, w pomniku, w roślinie. Ten, kto kocha kogoś to rozmawia z nim. Musi być ktoś mu równy. Bóg wieczny samotnik? Nie byłby Bogiem. Musi być miłość względem Osób. Trójca Święta od zawsze istniała jako miłość wpisana w Osobę Ojca i Syna i Ducha Świętego. Bóg jest doskonałą miłością, a doskonała miłość może zaistnieć tylko między równymi sobie Osobami. Nawet człowiek nie może się spełnić w miłości do istot niższych gatunkowo. Przywiązanie tak, ale nie miłość. Można lubić, ale nie wejdzie się $\mathrm{w}$ porozumienie emocjonalne, $\mathrm{w}$ relację kochania równo gatunkowo. Jeden Bóg i Miłość jako więź Ojca z Synem i z Duchem Świętym. Duch Święty obiecany przez Jezusa światu, to nie bezosobowa moc, energia. „Przyjdzie Duch Prawdy i nauczy was całej prawdy”. Wiatr nie mógłby nauczać o tajemnicach Bożego istnienia (por. J 3, 3-13). Ojciec nie pochodzi od nikogo,

26 Por. Jan Paweł II, W Imię Trójcy Przenajświętszej..., s. 91-106.

27 Tamże, s. 371-405. 
Syn jest zrodzony, a Duch Święty jest Osobą, a nie mocą. Duch Święty mówi „Ja”. Gdzie jest „Ja”, tam jest Osoba ${ }^{28}$.

Im bardziej poznajemy Boga, tym bardziej rozumiemy siebie, bo naszym przeznaczeniem jest On. Jak nie znamy naszego przeznaczenia, nie wiemy kim jesteśmy ${ }^{29}$. Bóg chce nas zaprosić do swego życia, by nie tylko Mu się „przyglądać”, ale w Nim żyć. Ziemski świat ograniczony swoją biologiczną egzystencją nie daje nam gwarancji na „długowieczność”, ale Bóg tak. On nas zaprasza do uczestniczenia w „Bóstwie” ${ }^{30}$. Wierzyć czy nie wierzyć w to? Jeśli tak będzie rzeczywiście po naszej śmierci w niebie, to co najmniej z tego względu warto wierzyć, że tak może tam być. By nie być rozczarowanym „na wieki”, gdy takiego Boga w Trójcy Świętej Jedynego ujrzymy, a nie będziemy czuli do Niego żadnej miłości. Niech Duch Święty usposabia nas do ożywienia w sobie miłości do Boga: „Przyjdź jako źródło pustyni, z mocą do naszych serc. O, niech twa moc uzdrowienia, dotknie, uleczy nas już".

„Duch Prawdy doprowadzi was do całej prawdy” (J 16, 13). Krótki czas obecności Jezusa wśród Apostołów zapoczątkował w nich wzrost zasianego w ich serca małego ziarna wiary. Byli wtedy sposobni przyswoić sobie tylko niewielki zakres rozumienia Jego Osoby. Do pełnej prawdy o Nim miał ich doprowadzić Duch Święty. Podobnie i nasze rozumienie Chrystusa jest w skali początkowego zaznajamiania się z Nim, bo często przygniata nas wielkość „nieznajomości” Jego potęgi. Mierząc ludzką miarą przycinamy prawdy Boże do ludzkich rozmiarów. A w Bogu są takie głębie, że ciągle odkrywamy w Nim coś nowego. Jezus „uwzględnia” realistycznie naszą ograniczoność poznania. Podobnie brał pod uwagę i wąski zakres rozeznania ludzkiego w sferze przyjęcia Objawienia. Mówił do swoich uczniów: „Jeszcze wiele mam wam do powiedzenia, ale teraz jeszcze znieść nie możecie" (J 16, 12). Może mamy silne ramiona do dźwigania ciężarów codziennego życia, ale balast „bycia chrześcijaninem” łatwo wytrąca nas z równowagi, ugina kolana, „ścina z nóg”, chwieje stabilnością. W niepewności i braku orientacji wśród różnorodnych reklam o dobrym życiu, o bio-życiu, o zdrowym ekologicznym odżywianiu się, o wygranym w promocji długim życiu, odnajdujemy tylko na drodze wiary to, co stanowi punkt wyjścia i autentycznie prawdziwy cel życia. Otwierając się na światło wiary rozeznajemy, że furtką życia jest wolność31. Jednak „nie wolno” nam czy raczej nam już „nie wypada”, bądź już nie potrafimy jej przeskakiwać, ale należy otworzyć ją

28 Por. Johannes Paul II, Der Heilige Geist, St. Ottilien 1993, s. 163-209.

29 Por. J. Ratzinger, Voici quel est notre Dieu..., s. 53-66.

30 Por. Jan Paweł II, Przemówienie na audiencji generalnej „«Poszukiwany» przez Boga, czlowiek «szuka» Boga" z 5.VII.2000, OsRomPol 1 (2001), s. 34-35.

31 Por. A. Guggenheim, Les preuves de l'existence de Dieu, Paris 2008, s. 118-121. 
odpowiednio wmontowaną klamką, którą jest prawda. Trzy wartości: wolność, prawda i życie wpisane są w naszą egzystencję, które spaja wiara ${ }^{32}$. Ona nadaje azymut naszemu bytowaniu na ziemi i odkrywa w nas pragnienie dojścia do prawdziwej wieczności. Wolność, prawda i życie. One tworzą triadę i wzajemnie się wspierają. Prawda prowadzi do wolności, a wolność nadaje kolory życia ${ }^{33}$. „Prawda skarbem wiedzy i mądrości źródłem, do życia prowadzi pod wolności godłem". I tej prawdy uczy nas Duch Święty. Trochę nie doceniamy działania Ducha Świętego. Dostrzegamy Osobę Ojca, Osobę Jezusa - Syna Bożego. Duch Święty jest „niecielesny”, co nam stwarza trudność wizualnego przedstawienia Go sobie na miarę naszej wyobraźni. Trudno Go nam zobaczyć, realnie Go wyobrazić. Ale jest On wszędzie tam, gdzie pojawiają się wątpliwości w wierze, gdzie jest potrzeba umocnienia zaufania Bogu, gdzie zaistniała prawda jest po ludzku nie do pojęcia. „Gdy zaś przyjdzie, On, Duch Prawdy, doprowadzi was do całej prawdy [...] i oznajmi wam rzeczy przyszłe" $(\mathrm{J} 16,13)$. I rzeczywiście naucza On nas o „rzeczach przyszłych”. Jak się rozwijamy intelektualnie i duchowo, to nagle dostrzegamy, że wiemy więcej, nawet rozumiemy już to, co wcześniej było dla nas nie do pojęcia. Poprzez odczytywanie na nowo „znaków czasów” według alfabetu wolności i prawdy odkrywamy treści, które są nam podawane do wierzenia ${ }^{34}$. „Duch Prawdy doprowadzi was do całej prawdy” (J 16, 13). Duch Prawdy poucza nas prawdą. Mówi On do nas z miłością, która skłania nas do odważnego zawierzenia Bogu mimo wielu spotykających nas codziennie ciężkich doświadczeń, nieprzewidywalnych zawirowań losu i upadków. On jest Tym, który „rozpala” w nas na nowo to, co z czasem mimo naszych wysiłków w wytrwaniu w podjętych przez nas dobrych postanowieniach poprawy uległo „zagaszeniu”. On jest Tym, który daje nam moc do odmiany życia na „torach dobra". On jest Tym, który w naszym zderzeniu się ze złem opatruje nam rany, podnosi na duchu, leczy urazy i goi ból. On jest Tym, który daje nam nowe skrzydła do lotu w przestworza nieba, pomagając nam oderwać się od często nas krępujących ziemskich spraw ${ }^{35}$.

„Kto z nieba pochodzi, Ten jest ponad wszystkim” (J 3, 31). Ubogaceniem naszej daleko sięgającej perspektywy życia jest spoglądanie w niebo. Zadziwiające jest to, że patrząc w wysokie nad nami niebo nie mamy lęku przestrzeni. W przeciwieństwie do spoglądania w dól, kiedy odczuwa się lęk wysokości.

32 Por. J. Neumann, W nurcie wyzwań ludzkiego życia, [w:] Człowiek istota (po)znana, Antropologia teologiczna wobec potrzeb i wyzwań wspótczesności, (red.) A. Proniewski, Białystok 2015, t. I, s. 172-182.

33 Por. M. Gagliardi, La Verità è sintetica, Teologia dogmatica cattolica, Roma 2017, s. 143-144.

34 Por. J. Paoletti, L homme entre science et foi, Paris 2007, s. 61n.

35 Por. E. Sienkiewicz, Osoba ludzka w kontekście encykliki Benedykta XVI „Deus caritas est”, „Studia Koszalińsko-Kołobrzeskie” 13 (2008), s. 265-293. 
Z tego nieba płynie w naszą stronę blask słońca i życiodajny deszcz. Na nieboskłonie odczytujemy wiele gwiezdnych dróg i tworzymy z ich konstelacji mapę przestworzy kosmosu. Na niebie wszystko „wisi”. Nic nie spada. W czym to wszystko ma punkt zaczepienia? Jaka potężna jest zatem siła grawitacji i bogactwo zjawisk ruchu planet na różnorodnych orbitach. To za „ruchomą gwiazdą" przybyli do Betlejem Mędrcy ze Wschodu, którzy na ówczesne czasy byli najbardziej wykształconymi w zakresie astronomii. Znak gwiazdy został wpisany także w godło Narodu Wybranego jako „gwiazda Dawidowa”. Dla żeglujących na wielkich akwenach wodnych, gdy brak jest jakichkolwiek horyzontalnych punktów odniesień, gwiazda polarna naprowadza na właściwy kurs i wyznacza azymut.

Nieograniczona wizja nieba ma w swej potędze to, co człowiek czuje w swoim duchowym życiu. Przy zachowaniu harmonii i porządku duchowego wszystko funkcjonuje w miarę dobrze w myśl prawego sumienia. Gdy pojawi się jednak grzech, wówczas duchowość zaczyna tracić stabilny korytarz orbity wokół Boga, a siły ciężkości sprawiają trudności w zapanowaniu nad równowagą i stabilnością duchowych przeżyć ${ }^{36}$. O potędze nieba słyszał od samego Jezusa namiestnik rzymski Poncjusz Piłat, który w dialogu ze Skazańcem „dowiedział się”, że ma władzę nie od cezara, ale z nieba: „Nie miałbyś żadnej władzy nade Mną, gdyby ci jej nie dano z góry" $(\mathrm{J} 19,11)^{37}$. Te słowa Jezusa naprowadzają nas na naszą jedność trwania z niebem. Z nieba przyszedł na ziemię Chrystus, który nas do nieba prowadzi. W swoim orędziu o królestwie Bożym wskazuje na niebo jako miejsce wiecznego przebywania ludzi po czasie ziemskiej egzystencji ${ }^{38}$. Wielu poszukujących Boga kierowało swe spojrzenie i serca ku niebu. Na nieboskłonie wypatrywano zjawiska Bożej mocy. Coś ma więc w sobie niebo. Jest chęć poznania tego, co ono w sobie kryje. Niewyobrażalne dla naszej mentalności „odległe miejsce” jednak separuje nas od entuzjazmu podążania do niego. $\mathrm{Z}$ doświadczenia znamy, że przyjdzie czas naszego odejścia z tego świata. I to bez tego, co się „przy sobie ma”. To niejednokrotnie nad wyraz przerasta nasze minimum nawet lekko sfolgowanego fantazjowania. A jednak! Przychodzi najczęściej z wiekiem taka chwila, że nie mieścimy się już na ziemi. Nie tylko odchodzący spośród nas do wieczności coś już nam mówią, ale i sami odczuwany z wiekiem zbliżający się kres naszego ziemskiego bytowania. To uświadamia nam i już nastraja duchowo na coś, co jest związane $z$ wiecznością, z niebem. Tam zamierzamy przecież być, gdy prawa biologii już w nas nie będą funkcjonowały. Modlimy się o niebo, szukamy wstawiennictwa z nieba, przyzywamy

36 Por. B. Rey, Pour des célébrations pénitentielles dans l’esprit de Vatican II, Paris 1995, s. 61n.

37 Por. V. Messori, Il a souffert sous Ponce Pilate..., s. 105-114.

38 Por. J. Neumann, Idea zbawcza Królestwa Bożego, Warszawa 2000, s. 27-33. 
orędowników z katalogu wielu świętych i błogosławionych, ufamy w opiekę Anioła Stróża, przewodnika po naszych drogach przydzielonego nam przez Boga od chwili naszego poczęcia. Z Katechizmu Kościoła Katolickiego wiemy, że po śmierci naszej będzie Sąd Boży, niebo czyściec albo piekło. I okazuje się, $\dot{z}$ e to wszystko jest dla ludzi, piekło te $\dot{z}^{39}$.

Zatroskanie Boga o każdego z nas ma swoją perspektywę w wieczności. „Aby każdy, kto w Niego wierzy, nie zginął, ale miał życie wieczne” (J 3, 16). Bóg jest życiem! Aczkolwiek został przez nas ludzi ukrzyżowany i pogrzebany, to zmartwychwstał! On daje życie! Przekazuje życie zarówno doczesne jak i wieczne. Tylko On jest Dawcą życia, chociaż niejednokrotnie człowiek uzurpuje sobie prawo do życia. To jednak po swoim ziemskim życiu każdy odpowie przed Stwórcą, co uczynił ze swoim życiem od Niego otrzymanym i jak wpływał na życie innych, których los okazał się różnoraki. Rodzice dają doczesną tylko egzystencję swemu potomstwu, zaś Bóg - życie w wieczności. Rodzice nie obiecują nam wieczności, tylko do niej wychowują i prowadzą. Nadto, o wieczności możemy co najmniej pomarzyć, a nie o niej decydować, komu moglibyśmy ją przydzielić i gdzie ją zlokalizować. Nie orientujemy się w topografii naszej planety, a wynosząc się w przestworza szybko wracamy jednak na ziemię, bo mamy lęk przestrzeni.

Słowa Jezusa: „Kto wierzy w Niego, nie podlega potępieniu, a kto nie wierzy, już został potępiony" $(\mathrm{J} 3,18)$ zmuszają każdego z nas do podjęcia świadomej decyzji opowiedzenia się „za” Bogiem albo „przeciw” Niemu. Innej alternatywy Chrystus nam nie daje. Możemy wprawdzie lawirować, tak jak wielu lekceważąco traktuje sprawy Boże i Zbawienie, to jednak przychodzi chwila, krótki nieraz moment refleksji i opamiętania się. To może być nagłe „zatrzymanie się” przed murem w ślepym zaułku, do którego nas wprowadził marazm i pokusy świata. To może być i rozłożone w czasie, niepozbawione dywagacji, dysput, mędrkowania, które okaże się rzucaniem piasku na wiatr. Może to być także zainspirowane poszukiwaniami prawdziwych wartości życia, a nie tylko „lukrowego ciasta" i ulotnej melodii. Można tańczyć całe życie, ale z czasem zabraknie sił, a zmęczenie nie pozwoli dłużej bawić się życiem zarówno swoim jak i innych. W swym opowiedzeniu się, czy „wierzę” Chrystusowi czy w Niego „nie wierzę”, stawiam na szali decyzję z całą swoją odpowiedzialnością i konsekwencjami. Bóg chce zbawić każdego z nas, ale ten, kto z własnej i nieprzymuszonej woli „nie życzy sobie Boga", na własne życzenie potępia się. W wieczności jest życie albo z Bogiem, albo bez Niego. I tam będziemy, gdzie chcemy iść. Warto wpatrywać się w życie ludzi w podeszłym wieku. Są oni żywymi bibliotekami z wielkimi zbiorami spisanych w sobie przeróżnych historii i dramatów. Posłuchanie ich

39 Por. J. Ratzinger, Eschatologia - śmierć i życie wieczne, Poznań 1984, s. 234-258. 
życiowej mądrości z pewnością uchroniłoby jakże wielu młodych na początku swych „wyjść z domu w świat” przed podobnym zagubieniem się w szuwarach grzechu, przed ryzykownym hazardem o szybkie posiadanie bogactw, przed zaplątaniem się w „zdawkową przygodę miłosną" i jej skutki.

„To bowiem jest wolą Ojca mego, aby każdy [...] miał życie wieczne” (J 6, 40). Jezus otwiera słuchającym Go „odrzwia” tajemniczego nieba i ukazuje im tam panujący stan życia wiecznego. Dla wielu wykraczało to poza granice ich wyobraźni i było niemożliwością skojarzenia tego, o czym mówił Jezus z tym, czego doświadczali dotychczas w rzeczywistości swego ziemskiego bytu. Chrystus otwierając im oczy mogące zerknąć za horyzont ludzkiej egzystencji i mogące „zajrzeć” w świat nadprzyrodzony, zachwycają się ofiarowanym im darem królestwa Bożego. On jako Syn Boży w ludzkiej naturze uobecniał sobą prawdziwie istniejącą wieczność ${ }^{40}$. „Jest wolą Ojca mego, aby każdy [...] miał życie wieczne” (J 6, 40). Jezus mówi o celu swej misji. „Ja jestem” chlebem żywym, który was karmi. „Ja jestem” dobrym pasterzem, Który was prowadzi do Bożej owczarni. „Ja jestem” winnym krzewem i daje wam życiodajne soki wzrostu duchowego. „Ja jestem” światłością, która oświeca wam drogi prowadzące do nieba. „Ja jestem” źródłem wody żywej, która gasi ludzkie pragnienia. „Ja jestem” z wami, dlatego „niech się nie trwoży serce wasze”. „Ja jestem” z wami, „nie lękajcie się”. „Ja jestem” Tym, który zstąpił z nieba, aby dać wam życie wieczne. „Ja jestem” z wami „aż do skończenia świata”. „Ja jestem” Zmartwychwstaniem i życiem, kto wierzy we Mnie, nie umrze na wieki ${ }^{41}$.

Po dokonanym cudzie rozmnożenia chleba na pustkowiu i nakarmieniu wielotysięcznej rzeszy, zaczyna docierać do świadomości wielu, że Jezus jest rzeczywiście „Kimś” nie z tego świata. Jego nauka i dokonywane cuda wprawiały w osłupienie i zachwyt każdego. Nawet uczeni w piśmie, faryzeusze i saduceusze nie mieli odwagi wdawać się w wielkie dyskusje z Rabbim z Nazaretu, gdyż On w jednym momencie publicznie ujawniał ich podstępne działania. Gromadzący się ludzie przy Chrystusie zaczynają „żyć Jezusem”"42. To pomaga im rozeznać prawdę o sobie samym stając przed Chrystusem tak blisko, na odległość wyciągniętej dłoni. „Chociażbym mogła dotknąć się frędzli Jego płaszcza, a będę zdrowa", cisnęła się przez tłum z tą myślą chora od wielu lat kobieta. Mimo niedomagań swego zdrowia i tłumu oblegającego Jezusa, uparcie cisnęła się $z$ tym pragnieniem wierząc, że otrzyma łaskę zdrowia od Niego. Gdy zaś tłum był tak wielki, że nie było możliwości podejść do Chrystusa, rozebrano dach domu i spuszczono sparaliżowanego przed stojącego w środku Jezusa. Wszystkie

40 Tamże, s. 181-213.

41 Por. B. Rey, Jésus-Christ chemin de notre foi..., s. 54-55.

42 Por. tenże, Jesus, l'aujourd hui de Dieu, Paris 1994, s. 23n. 
możliwe drogi do Chrystusa są już „przetarte” i wszystkie się sprawdziły. Jaką wybierzemy „ścieżkę” zbliżenia się do Niego? Możemy oczekiwać Go na drodze jak niewidomi, żebrzący, jak wspinający się na sykomorę Zacheusz. Możemy przyjść do Niego i nocą jak Nikodem czy w samo południe jak spotkała Go Samarytanka przy studni Jakubowej. Gdy jeszcze nam brak odwagi, może inni nam pomogą Go spotkać? Miała „szczęście w nieszczęściu” kobieta pochwycona na cudzołóstwie, bo została „przywleczona” do Niego, by ją nie tylko mógł zobaczyć, ale by wyraził zgodę na prawne ukamienowanie jej za ten czyn. A On ją ocalił! Dotychczas nie interesowała się Jezusem, chociaż zapewne o Nim słyszała. Teraz szła za Nim w szeregach tłumu „na kolanach” wdzięczności za ocalenie.

\section{Moc życia Bogiem}

„Potrzeba, aby wywyższono Syna Człowieczego, aby każdy, kto w Niego wierzy, miał życie wieczne" (J 3, 15). Dla wielu środowisk różnych kultur znana jest osoba Jezusa Chrystusa jako Syna Człowieczego. Samo pojęcie „Syn Człowieczy” stanowi jednak i dla chrześcijan trudność zrozumienia tej tajemnicy o wspólistnieniu w Jezusie - i Boga i człowieka, w jednej Osobie istnienie na zasadzie unii hipostatycznej dwóch natur - Boskiej i ludzkiej. „A wy co mówicie, kim Ja jestem?” (Mk 8, 29). Pytanie stawiane każdemu z nas i w każdej sytuacji zmuszające do podjęcia decyzji opowiedzenia się „za” Jezusem względnie „przeciw” Niemu. W tym Jezusowym pytaniu dostrzega się „zakodowaną” prawdę Chrystusa o sobie jako Bogu. Jej przyjęcie wprowadza nas w sferę oddziaływania Bożej łaski wiary ${ }^{43}$.

W wielu prośbach o uzdrowienie, skierowanych do Jezusa pojawia się zawsze w odpowiedzi Chrystusa warunek: „Czy wierzysz?”. Zatem, co stanowi istotę zaistnienia spełnienia ludzkiego „błagania” skierowanego do Boga? Wiara! W niej zawarta jest istotna treść ludzkiego życia zakorzenionego w „glebie” doczesnej egzystencji i zarazem wieczności. Dlatego teologia zaszeregowała wiarę do cnót teologicznych wraz z jej relacją do nadziei i miłości (por. 1 Kor 13, 13). To pozwala poznać wzajemnie ich przenikanie się. Gdzie istnieje wiara, tam i pojawia się nadzieja, które wprowadzają nas w orbitę oddziaływania Bożej miłości. Gdzie jest brak wiary lub jej moc słabnie, wówczas urealnia się zwątpienie. W wierze i w jej przeżywaniu pojawia się nierozłącznie zaufanie i zwątpienie, co jest doświadczaniem wiary ${ }^{44}$. Dostrzegając dziejące się w świecie zło, niejako spontanicznie kierujemy do Boga „prośbę”, by On zadziałał i „narzucił”

43 Por. tenże, Jésus-Christ chemin de notre foi..., s. 29-39.

44 Por. Jan Paweł II, Przemówienie na audiencji generalnej „Mitość Boga czeka na odpowiedź czlowieka" z 13.II.2002, OsRomPol 4 (2002), s. 13. 
ludzki sposób weryfikacji dobra i zła. Jednak tu jest ważna kwestia wolnej woli człowieka, która wpływa na decyzje ludzkie. Jeśli człowiek na Sądzie Bożym będzie zdawał sprawę z dokonanych przez siebie rzeczy dobrych i złych, wówczas „narzucona” człowiekowi decyzja Boga kwestionowałaby wolną wolę człowieka w jego orzekaniu o podjętych przez siebie decyzjach i wyborach. Bóg niezwykle jednak delikatnie przeplata nasze życie swoją łaską na miarę naszych pragnień i duchowych potrzeb. Przejawem tego jest z naszej strony, jako wierzących, ożywiająca się inicjatywa rewitalizacji w nas duchowości chrześcijańskiej opartej na pragnieniu życia autentyczną wiarą w Boga. Otwarcie się na Objawienie Boże i szczere zaufanie Bogu może pomóc nam w wyborze właściwej drogi do „źródła życia i świętości” po dobro i mądrość emanujące z Boga ${ }^{45}$. Bóg objawia się nam dlatego, że chce! Jest to dar nadprzyrodzony i jednocześnie dar osobowy, gdyż Bóg poprzez objawienie się nam daje samego siebie wraz z całą swoją „rzeczywistością”. A współczesny świat szukał i nadal szuka coraz to nowych „rzeczywistości” swego samorealizowania się, zapominając, że tylko w Bogu jest naprawdę to, czego się szuka. Współczesny „modny świat” preferuje „życie bez Boga”, co w konsekwencji „gasi” wiarę i wypacza ludzkie dążenia. Widać to w separowaniu społeczności od liturgii, od tradycji religijnej, co stało się wyalienowaniem prawdziwych duchowych pragnień człowieka ${ }^{46}$. W rezultacie zapomina się, że Bóg jest głównym przedmiotem wiary i jej motywem jako nieomylny i prawdomówny. Gdy pośredniczy między Bogiem a człowiekiem Objawienie, wówczas ma swój sens istnienie „rzeczywistości” Kościoła. Ale, gdy neguje się Kościół i święte sakramenty, wówczas życie duchowe powoli staje się „jałowe i nużące”. Dlatego potrzeba nam pełnego zawierzenia Jezusowi, który spogląda na nasze zmagania na drodze wiary z wysokości krzyża. Z niego to ma Chrystus o wiele dalszy zakres spojrzenia na to, co wyrasta na naszej drodze wiary, na to, co nam może pomóc w zdążaniu do nieba i na to, co winno się ominąć, by nie zwiodło nas to „coś” na manowce.

„Ale teraz idę do Ciebie i tak mówię, będąc jeszcze na świecie, aby moją radość mieli w sobie w całej pełni” (J 17, 13). Syn Boży jest „blaskiem” Boga Ojca, a w Nim ono urzeczywistnione emanuje na cały świat. Przez to staje się Chrystus objawieniem prawdy o Bogu Ojcu. Tym samym jest Słowem Ojca jako „Bóg z Boga, światłość ze światłości, Bóg prawdziwy z Boga prawdziwego”, Tym, Który zaświadczył o Bogu Ojcu, Którego nikt nie widział (por. J 1, 18). Świat w tajemnicy Trójcy Świętej odczytał prawdę Bożą, że Ojciec, Który nie jest Słowem, ale „ciszą wieczności”, objawił się przez swojego Syna Jezusa

$45 \quad$ Por. Franciszek, Prawda jest spotkaniem..., s. 529-531.

46 Por. J. Neumann, Tendencje sekularystyczne we wspótczesnej teologii, [w:] Kontrchrześcijaństwo (red.) A. Sokołowski, Pieniężno 2009, s. 31-41. 
Chrystusa, Który jest Jego Słowem „wychodzącym z ciszy”. Jezus przychodzi na świat, by mówić o wieczności, a jako Słowo Ojca zostaje intronizowane i otoczone chwałą przez samego Ojca. Zatem Bóg, który mówi przez Syna, mówi do ludzi w Kimś jednym, którym jest Chrystus - Jego Syn ${ }^{47}$. To Boże synostwo określa sam Jezus jako swoją właściwość ontologiczną. To przekłada się na nową jakość przekazu Objawienia Boga i jego interwencji w historię dziejów świata. Jezus jako Syn Człowieczy, przyjmując ludzką naturę, ożywia w człowieku uśmierconą grzechem świętość. Ten fakt podkreśla zarazem jedność i pełnię solidarności Boga z człowiekiem i z ludzką słabością. Poprzez cierpienie i doświadczenie śmierci ludzkiej staje się Jezus fundamentem nowego kapłaństwa i spełnieniem ofiary paschalnej celebrowanej w nawiązaniu do starotestamentalnych obrzędów tradycji żydowskiej.

Misja Jezusa w aspekcie eschatologicznym urzeczywistnia pełnię miłości Boga Ojca - Stwórcy względem świata i wszystkich ludzi. „Tak bowiem Bóg umiłował świat, że Syna swego jednorodzonego dał, aby każdy, kto w Niego wierzy, nie zginął, ale miał życie wieczne" ( 3,16$)$. Znamię wiary ma w tym przekazie odniesienie do prawdy, że Ojciec „zlewa” na swego Syna „przeznaczenie" świata i dokonanie odkupienia rodzaju ludzkiego ${ }^{48}$. Wszystko w zamyśle Bożym zostaje poddane Zbawieniu dokonującemu się w Synu i przez Syna. Ta „mowa” Ojca w Synu wyraża odwieczną wolę Bożą objawiającą się w darze nowego przymierza (por. Ef 1, 9-10). Dzięki woli Ojca wszystko ma już swe wypełnienie w dokonanym dziele Odkupienia świata przez Syna Bożego. Nie jest to już pewna idea Boga, która była zapowiedzią w zapisie historii dziejów, ale rzeczywiście dokonanym Odkupieniem człowieka. Bóg Narodu Wybranego staje się przez Jezusa i w Jezusie Bogiem wszystkich narodów wszystkich czasów. Bóg bowiem darzy swoją miłością stworzony przez siebie świat i ten świat podtrzymuje nadal przy życiu w jedności ze sobą. W tym wyraża się miłość Boga względem człowieka, że posyłając swego Syna na świat pragnie, aby każdy człowiek miał w Nim życie i w Jego łasce pełnię zjednoczenia z Nim. To ukazuje prawdę, że każdy człowiek jest wezwany do życia miłością emanującą z Boga i rozlewającą się na wszystkich ludzi. Dlatego posłał Ojciec swego Syna, aby „oznajmił tajemnicę swej woli według swego postanowienia, które przedtem w Nim powziął dla dokonania pełni czasów, aby wszystko na nowo zjednoczyć w Chrystusie jako Glowie: to co w niebiosach, i to, co na ziemi” (Ef 1, 9-10). W tym zawiera się bogactwo miłości Bożej względem człowieka, która raz wyrażona przez Ojca w stwórczym „Tak”, trwa niezmienne przez całe dzieje

47 Por. J. Raztinger, Voici quel est notre Dieu..., 185-201.

48 Por. Jan Paweł II, Wierzęw Jezusa Chrystusa Odkupiciela, Città del Vaticano 1989, s. 451-518. 
ludzkości wszech czasów ${ }^{49}$. Bóg kocha stworzony przez siebie świat, który jest niejako metaforą i symbolem Jego obecności. Świat jest przeznaczony Bogu. To wyraz miłości Ojca względem ludzkości, a posyłając na świat swego Syna ma na celu danie każdemu człowiekowi życie Boże, analogicznie do „tchnienia” danego w akcie stworzenia pierwszemu człowiekowi ulepionemu z gliny.

„Aby świat uwierzy1, żeś Ty Mnie posłał” (J 17, 21). „Pełnia czasów” stała się początkiem zapowiadanego Zbawienia świata podjętego przez Syna Bożego. Bóg sam interweniował niejako w bieg zdarzeń historii pokazując „przełom” w dziejach ludzkości. Tym „przełomem” jest Syn Boży, Jego Wcielenie, dzięki czemu świat otrzymuje w darze łaski nowy wymiar „zdążania do świętości”" Poprzez fakt, że Chrystus stał się pokornym sługą, została „otwarta” ludzkości droga dojścia do Boga Ojca szczególnie tym, którzy w danym czasie byli „zniewoleni” przez grzech. Jezus staje się Tym, Który w „czasie” rodzi wszystko, daje rozwój, pomnaża owoce dobra i prawdy. On jest początkiem, „trwaniem” i przyszłością czasu jako „pełni”. On jest Alfą i Omegą, Początkiem i Końcem, Chrystus „wczoraj, dziś i na zawsze” (Hbr 13, 8). Człowiek nie mogąc poznać Boga „bez Boga" doznaje pomocy od Odwiecznego Słowa, który pomaga ludziom poznać Ojca. Syn Boży poprzez osobowe objawienie siebie pozwala poznać światu Boga Ojca, gdyż poznanie Syna jest poznaniem Ojca. „Wszystko zostało objawione przez Słowo". Przez żywe Słowo zostaje poznany żywy i prawdziwy Ojciec, a istotą ,pełni” jest Objawienie Boga Ojca przez Odwieczne Słowo w ludzkim ciele. Fakt przyjścia na świat Syna Bożego nadaje dziejom ludzkości „nowość życia” widzianą w Osobie Jezusa Chrystusa. Sens „pełni czasów” jako dokonujące się Objawienie Boga w Synu Bożym nie jest tylko „pełnią” istniejącego świata w Jezusie i z Nim Boga Ojca, lecz także poznaniem doskonałości Boga. Jezus jest „miejscem” doskonałej w Nim obecności „mieszkającego” w Nim Ojca. Poprzez swoje Wcielenie stał się Chrystus „pełnią” w wymiarze posiadających i udzielanych światu darów Bożych łask. Bóg objawiając się człowiekowi na drodze wiary ubogaca świat swoimi darami, miłością, prawdą, życiem w łasce, gdyż sam jest źródłem dobra, prawdy, miłości, prawdziwego życia ${ }^{51}$. Przez swego umiłowanego Syna objawia to wszystko, co jest Jego zamiarem od wieczności, co dokonuje się w teraźniejszości i co przygotował ludziom na wieki. To otwiera każdemu z nas horyzont poznania swego miejsca w danym „czasie i przestrzeni” swej egzystencji i skłania do podjęcia decyzji wyboru „powrotu” na drogę Zbawienia z dotychczasowego kroczenia ścieżkami grzechu. „Wszystko, co jest pod słońcem" - życie ludzkie i jego sens - ma w swej perspektywie przemijania

49 Por. J. Ratzinger, Voici quel est notre Dieu..., s. 79-95.

50 Por. Jan Paweł II, Wierzę w Kościót..., s. 111-114.

51 Por. J. Chyła, Jezus Chrystus Jana Pawła II, Pelplin 2007, s. 37-86. 
i ograniczoności sposobność wejścia w „koleiny filozofii pełni” ukazanej światu w Betlejem, gdzie „Słowo stało się ciałem i zamieszkało wśród nas” (J 1, 14). Jezus sobą sprawił, że „pełnia czasów” stała się „czasem pełni”. W tym sensie człowiek i jego natura nie została „unicestwiona”, lecz na nowo otrzymała łaskę bycia taką, jaką była od stworzenia do chwili zaistnienia w niej grzechu pierworodnego ${ }^{52}$.

W „staniu się” Słowa dopełnił się dialog między Bogiem i światem, którego zapowiedzią był w Narodzie Wybranym dialog Jahwe z Izraelitami. W widzeniu zaś Jezusa przez ludzi ukazał się sam Bóg o obliczu miłości stwórczej i zbawczej. „Kto Mnie widzi, widzi i Ojca mego”, powie Jezus do Filipa, gdy ten prosił Go: „Pokaż nam Ojca” (por. J 14, 9). Ze „słuchania” Syna Bożego emanuje „widzenie” Ojca. Kto zatem „widzi” Syna Bożego, ten „słucha” Ojca. W tej analogii „słuchanie” jest „prawdziwą ikoną Niewidzialnego”. W Słowie można „słuchać” Ojca, który staje się obecny w Słowie i w „słuchaniu”. To ma swoją wymowę w wydarzeniu zbawczym, gdy Ojciec, który przychodzi w Synu, cierpi aż do Męki na krzyżu, aby być „usłyszanym” ${ }^{53}$. Cierpi, aby otworzyć uszy. Dlatego Jezus dla tak wielu z grona głuchoniemych przywrócił słuch i mowę, aby „usłyszawszy” mogli „głosić” światu - Kim jest Bóg (por. Mk 7, 31-37).

\section{Poszukiwanie Jezusa}

Po cudownym rozmnożeniu chleba Apostołowie „o zmierzchu zeszli nad jezioro i wsiadłszy do łodzi przeprawili się przez nie do Kafarnaum. Nastały ciemności, a Jezus jeszcze do nich nie przyszedł" $(\mathrm{J} 6,16)$. Odpłynęli bez Jezusa. Można domniemywać, że Jezus sam im nakazał, by odbili od brzegu i przeprawili się na drugą stronę jeziora. Tak uczynili przypuszczając, że Jezus inną łodzią z innymi dopłynie. Ewangelista św. Jan zapisał w swoim przekazie, że łódź Apostołów była już na jeziorze około 25-30 stadiów od brzegu, gdy w mrokach spowijających taflę jeziora dostrzegają Apostołowie swego Mistrza. I zobaczyli Go nie w łodzi, ale kroczącego po wodzie: „Ujrzeli Jezusa kroczącego po jeziorze. [...] I przestraszyli się" (J 6, 19). Jeden stadion to odległość 185 metrów. Zatem byli od brzegu około 5 kilometrów. Jako rybacy mieli rozeznanie, że w takiej odległości od brzegu mają pod sobą kilkudziesięciometrową głębię. Nadto była nocna ciemność ograniczająca widoczność i ,jezioro burzyło się od silnego wiatru" $(\mathrm{J} 6,18)$. Te warunki żeglowania sprawiały trudność doświadczonym rybakom w manewrowaniu łodzią. Koncentrowali swoją uwagę na sile wiatru, by odpowiednio ustawić i utrzymać żagle, a nawet wspierać się siłą rąk

52 Por. J. Troska, Człowiek w nauczaniu Jana Pawła II, [w:] In persona Christi (red.) K. Góźdź, Lublin 2009, t. I, s. 489-506.

53 Por. V. Messori, Il a souffert sous Ponce Pilate..., s. 331-339. 
w wiosłowaniu naprzeciw wzmagającym się falom, które znosiły ich z obranego kursu. I oto nagle wyłania się przed nimi chodząca po wodzie postać, która w ich ocenie nie powinna w tym miejscu być! „I przestraszyli się” $(\mathrm{J} 6,19)$. Wpadli w przerażenie i strach. I oto słyszą znany im głos, który rozpoznają: „To Ja jestem, nie bójcie się” (J 6, 20). Tak mógł powiedzieć tylko Jezus - „Ja jestem". Chcieli Go zabrać do łodzi, ale łódź znalazła się natychmiast przy brzegu, do którego zdążali" (J 6, 21). Może się zastanawiali wtedy, co się stało z łodzią, którą prawdopodobnie, jak przypuszczali Apostołowie, mógł płynąć Jezus? Czy uległa zatonięciu i trzeba pośpieszyć na pomoc rozbitkom, by ich ocalić? Ale nic o tym nie wspomniał Jezus, by ich naprowadzić na ewentualne miejsce niefortunnego zdarzenia. Ich łódź „znalazła się natychmiast przy brzegu, do którego zdążali" (J 6, 21). Jeśli Jezus sprawił, że ich bezpiecznie do brzegu i „szybko” sprowadzil, to zapewne i innych, z którymi być może płynął, także do brzegu już dowiódł. Lęk zagasł. Wysiedli na brzegu. Mieli już grunt pod nogami. Wtedy zapewne docierały do nich wyrywkowe myśli z odbytego rejsu. Wypłynęli bez Jezusa, a dopłynęli z Nim. Jak mógł On chodzić po wodzie? To ich nurtowało i niepokoiło, chociaż to, co im zatrwożonym powiedział, żeby się nie bali, przyjęli ze spokojem. Jak więc Bóg do nas mówi? Nie tylko spogląda $z$ oddali w naszą stronę, jak sobie dajemy radę. On do nas zmagających się z przeciwnościami życia podchodzi i pociesza. Bo każdy z nas przeżywa burze, życiowe sztormy, dramaty i rozterki codzienności, zwątpienia czy rozpacz i poczucie bezradności. Ale gdy wypatrujemy w „ciemnościach” wytężonym wzrokiem Jezusa, widzimy Go zbliżającego się do nas. To napawa nas radością, że jest On nas blisko „na wyciągnięcie ręki”. A On może wszystko. I chleb rozmnoży, zaspokoi głód słowa i chleba, przywróci zdrowie, w smutku pocieszy, otrze łzy bólu i cierpienia, uleczy rany duszy i ciała. On to może, bo jest Bogiem! On może zmienić i prawa natury są mu posłuszne. Jeśli to Go „słucha”, to jak jest z naszym Jemu posłuszeństwem? Jakiego widzimy Jezusa na horyzoncie naszego życia? Zjawę paraliżującą nas strachem i lękiem sądu, przypominającego jedynie ze złych przeżyć „jakiegoś” Chrystusa? By to zmienić, potrzeba nam odwagi ponownego wypłynięcia na głębię w ciemności rejsu po wzburzonym jeziorze miotających nas grzechów, aby zmierzyć się z burzą w swoim sercu i spotkać podchodzącego do nas Jezusa mówiącego z miłością i troską o nas: „To Ja jestem, nie bójcie się” (J 6, 20).

„Przybyli do Kafarnaum i tam Go szukali” (J 6, 24). Przekaz wiadomości i wszelkiej informacji w tamtej epoce był o wiele powolniejszy, aniżeli w naszych czasach. Wypytywano się i porównywano relacje, analizowano zasłyszane wiadomości, aby dobrze zlokalizować kogoś lub coś, z kim chciano się spotkać lub coś znaleźć. Sam fakt podróżowania, udania się w drogę wiązał się z niemałym wyrzeczeniem, trudem i ryzykiem. Ludzie z tłumu idący za Jezusem pozostawiali 
swoje domostwa na pewien czas pod opieką sąsiadów lub krewnych. Należy podziwiać podążających za Jezusem. Musieli bowiem na ten okres „marszu za Jezusem" zostawić konieczne prace w polu, w winnicy, trzeba było zlecić doglądanie domowej trzody innym. Kierowani wskazaniami spotkanych po drodze, idą gromadnie poszukując Nauczyciela z Nazaretu. Spotkani dowiadują się więcej o Tym, kogo „idący tłum” pragnie odnaleźć. Wielu dołącza się do „idącego tłumu” w miarę zaciekawienia i możliwości. W poszukiwaniu Jezusa płyną łodziami, które na co dzień służyły im do połowu ryb. Teraz są w ich posiadaniu jako środki transportu. Poszukują Chrystusa w nadziei, że Go znajdą. Dlaczego Go szukają? Co On im takiego dał, że chcą do Niego dotrzeć i być pewien czas przy Nim? Dla coraz większej rzeszy przyświeca na razie jedynie zamiar, ale ogólnie panuje przekonanie, aby Go odnaleźć i obwołać swoim królem. Nakarmił ich cudownie rozmnożonym chlebem! To było głównym motywem poszukiwania Jezusa ${ }^{54}$. Gdy Go odnaleźli na przeciwległym brzegu Jeziora Galilejskiego pełni zachwytu i zarazem zdziwienia pytają: „Rabbi, kiedy tu przybyłeś? (J 6, 25) Samo pytanie jest jakby dyskretnym usprawiedliwieniem się wolniej „idącego tłumu”. Wraz z osobami starszymi, zmęczonymi trudami drogi, chorymi, dziećmi, nie zawsze dotrzymywano szybkiego tempa komuś idącemu samemu czy w małej grupie sprawniejszych osób. W sytuacji już odnalezienia Jezusa nawiązuje się dialog. Jest zadowolenie ze spotkania z Rabbim, ale i uważne zasłuchanie się w to, co On im powie w chwili już ich dotarcia do Niego. A Jezus mówi im, jakby czytając z pragnień ich serc: „Zaprawdę, zaprawdę powiadam wam: Szukacie Mnie nie dlatego, żeście widzieli znaki, ale dlatego, żeście jedli chleb do sytości" $(\mathrm{J} 6,26)$. Taki był rzeczywiście ich zasadniczy cel odnalezienia Jezusa. Ale i rodzą się owe pragnienia thumu podczas zasłuchania się w naukę Jezusa ${ }^{55}$. „Cóż mamy czynić, abyśmy wykonywali dzieła Boże?” (J 6, 28). W odpowiedzi słyszą: „Abyście uwierzyli w Tego, Którego On posłał” (J 6, 29), tj. Syna Bożego. Izraelici wierzyli w obecność Jahwe, który wybrał ich naród jako swój i obdarza ich swoją opieką mimo nieraz spadających na Wybrany Naród wielu doświadczeń i klęsk. Ale On jest ich Bogiem jedynym. Ten monoteizm, wiara w istnienie jednego Boga, ich scalał w wierze i kulcie ${ }^{56}$. Teraz słyszą, aby „uwierzyli w Tego, Którego On posłał”, a Którego oni rzeczywiście swymi oczyma widzą, słuchają i poszukują. A to, co Jezus czyni przerasta ich ludzką wyobraźnię. Wielu doznając duchowych przeżyć otwiera swoje serca na naukę Jezusa, podchodzi z wiarą do tego, co

54 Por. C. Bellon, Die Eucharistie ist mehr, viel mehr, „Communio e Communicazione” 21 (2000), s. 44-47.

55 Por. A. Dziuba, Dynamika wiary, Częstochowa 1997, s. 119-150.

56 Por. S. Natoli, Dio è le rivelare, „Filosofia e Teologia” 3 (1996), s. 532-543. 
słyszy w przesłaniu Chrystusa o królestwie Bożym, obserwuje styl życia Jezusa, Jego dobro i miłość względem zranionych grzechami czy opętanych przez złe duchy, których uzdrawia, a nawet umarłych wskrzesza. To może czynić jedynie Bóg. To staje się dla wielu czytelnym znakiem obecności Boga wśród nich ${ }^{57}$. Wielkie rzesze widzą w Jezusie „Bożą pieczęć, którą naznaczył Go Bóg Ojciec” (J 6, 27). I wielki entuzjazm zaczął „kwitnąć” w duszach wielu z tłumu, a jego apogeum przeżyje Jezus w dniu swego wjazdu do Jerozolimy w Niedzielę Palmową. Wszyscy wybiegną Mu naprzeciw, słać będą swe płaszcze na Jego drodze i wołać „Hosanna, hosanna Synowi Bożemu” (por. J 12, 13).

„Jakiego dokonasz znaku, abyśmy [...] Tobie uwierzyli. Cóż zdziałasz? Ojcowie nasi jedli mannę na pustyni" (J 6, 30). Otoczenie Jezusa stanowili ludzie prości, konkretni, bez aspiracji przekraczających horyzont codziennej pracy $\mathrm{w}$ domowym gospodarstwie. Dla ich praojców otrzymany dar manny z nieba stał się pożywieniem na czas ich przejścia przez pustynię po wyjściu z niewoli egipskiej. Na tę pamiątkę przechowywano w złotej Arce Przymierza chleb manny wraz z „zakwitłą laską” pasterską Aarona i kamienne tablice Dekalogu. Manna była pośrednim przedmiotem ich religijnego kultu. Do niej odwołuje się tłum i skłania Jezusa, by dokonał co najmniej takiego samego znaku, jaki widzieli ich przodkowie w cudzie spadającej z nieba manny. A mogli zażądać innego znaku. Jednak cudowne rozmnożenie chleba przez Jezusa sprzed kilku dni pamiętali jeszcze bardzo dokładnie i w tym celu Go szukali, aby obwołać Go królem. Domniemali, że Jezus, jako ich król zatroszczy się „z urzędu” o chleb swoim poddanym. To było dla nich zapobiegliwością, by już bez nadmiernej pracy mieć zawsze pod dostatkiem codzienny chleb. Jezus „spełnia” ich życzenie i wyjaśnia, że „dopiero Ojciec mój da wam prawdziwy chleb z nieba” (J 6, 32). Rzekli więc do Jezusa: „Panie, dawaj nam zawsze tego chleba” (J 6, 34). Odpowiedział im Jezus: „Jam jest chleb życia [...], kto we Mnie wierzy nigdy pragnąć nie będzie" (J 6, 35). Testament Jezusa. Trudno było słuchającemu tłumowi pojąć, że Jezus jest „żywym chlebem” ${ }^{\text {58 }}$. Dla nich chleb to był chleb $z$ mąki, wypieczony na ogniu, podobny do tego, jaki jedli na pustkowiu z rąk Jezusa po cudownym rozmnożeniu. To, co teraz słyszą o „żywym chlebie” z ust Chrystusa wprawia ich w zakłopotanie. Jezus jako „chleb żywy”? I tak jak Jemu współcześni, tak i my dzisiaj mamy często trudność ze zrozumieniem Jezusa. Trudno jest nam „przetrawić” Jego naukę i Jego samego jako „chleb żywy”! Zapewne pamiętamy jak z dziecięcą wiarą śpiewaliśmy w pieśni eucharystycznej w dniu naszej I Komunii św: „Jezusa ukrytego, mam w Sakramencie czcić,

57 Por. J. Chyła, Jezus Chrystus Jana Pawta II..., s. 232-270.

58 Por. J. Guitton, Tajemnica „rzeczywistej obecności” Chrystusa w Eucharystii, „Communio” 1 (1986), s. 83-88. 
wszystko oddać dla Niego, Jego miłością żyć. On się nam daje cały, z nami zamieszkał tu, dla Jego Boskiej chwały, życie poświęćmy Mu". Wyrośliśmy z biegiem lat już z pierwszokomunijnych strojów, jednak „kręgosłup” wiary w Chrystusa jest ten sam. Jezus ukrywając się pod postacią chleba wiedział, że człowiek ten chleb zawsze będzie spożywał. I rzeczywiście chleb nam się nigdy nie przejadł, chociaż to, co było do chleba - wielokrotnie tak. Chleb smakuje zawsze. Zrobiony z różnorakich zbóż, świeży, czerstwy, o różnorodnej formie. Chleb darzymy szczególnym szacunkiem, dajemy go proszącym o kromkę, nie wyrzucamy go na śmieci. Kryje on w sobie moc pożywienia dla zgłodniałego organizmu. Chleb nie rośnie sam z siebie, lecz wymaga ludzkiej pracy: zasiewu ziarna w glebę, przeorania roli, zbioru przez żniwiarzy, pracy młynarza, piekarza i rozdziału według potrzeb. Chleb jako „owoc ziemi i pracy rąk ludzkich”, gdy staje się mocą konsekracji Ciałem Chrystusa adorujemy i przyjmujemy ze czcią, będąc w stanie łaski uświęcającej. I tak jak chleb pokrzepia biologicznie organizm, tak Eucharystia umacnia nas duchowo w jedności z Jezusem w naszym przemierzaniu ziemskich dróg za $\mathrm{Nim}^{59}$. Odczuwana w sercu z Nim bliskość potęguje pragnienie trwania przy Nim, mimo zmęczenia czy bolesnych dla duszy naszych upadków w grzechy. By przyjąć Jezusa w Komunii św. musimy być wolni od grzechów ciężkich. To nas mobilizuje do jeszcze bardziej „uważnego życia”, by grzechy nie blokowały nam drogi prowadzącej do Boga. Pomocą jest obmycie się w źródle Bożego miłosierdzia, by po rachunku sumienia, żalu za swe grzechy, zadośćuczynieniu i mocnym postanowieniu poprawy szczerze wyznać w sakramencie pokuty to, co wstrzymuje nas od przyjęcia Eucharystii. Otrzymane Boże rozgrzeszenie otwiera na „bramy raju”, za którego „wrotami” jest czas i miejsce na przyjęcie „chleba życia” i trwanie w adoracji przed $\mathrm{Nim}^{60}$. „Jam jest chleb życia [...]. To jest chleb, Który z nieba zstępuje: kto go spożywa nie umrze” (J 6, 48-49). Użyte określenie „Chleb, Który z nieba zstępuje” odnosi Jezus do siebie, do swego przyjścia na ziemię w narodzeniu się w mieście Betlejem, którego nazwę tłumaczy się jako „dom chleba”. „Chleb, który z nieba zstępuje" (J 6, 48). Ludzkość zna dobrodziejstwa nieba: życiodajne opady deszczu, ciepło słońca oświetlające porę dnia i dające siłę roślinnej wegetacji. W mitologii zarówno greckiej, jak i rzymskiej, niebo było miejscem przebywania bogów. Gwiazdozbiory czytelne przy blasku księżyca ukazywały ludziom panującą harmonię przemieszczających się ciał niebieskich w bezkresnym kosmosie. Astronomia pozwalała człowiekowi zaglądać w „zakamarki” nieba. „Zachwyca” i zarazem „pyta” o spoglądanie w niebo i we wnętrze człowieka.

59 Por. J. Ratzinger, Ostatnia Wieczerza, a Eucharystia Kościoła, „Communio” 1 (1986), s. $162-174$.

60 Por. G. Bedouelle, Szczéśliwi zaproszeni na Ucztę Baranka, „Communio” 1 (1986), s. 9-15. 
Przysłowie ludowe: „Mówić głodnemu o niebie, kiedy on myśli o chlebie” ma coś z tej prawdy. Jakby analogicznie odnosił się i Jezus do tego, gdy mówi: "Jam jest chleb życia [...], który z nieba zstępuje: kto go spożywa nie umrze" (J 6, 48-49). Z tego „wysokiego nieba”, jak mówi Jezus zgromadzonym wokół siebie tłumom, On jako „chleb życia zstępuje” $(\mathrm{J} 6,48)$. Chleb i niebo scala się w jedno w Chrystusie. W Nim mogą słuchający Go dostrzec „rąbek” nieba, na tyle „zdolny do strawienia”, na ile potrafi on zaspokoić każdy „chwilowy głód”. I jak głód po pewnym czasie powraca, tak i nawroty do „przyjmowania Jezusa” wzmacniają cały proces cielesno-duchowej ludzkiej egzystencji. I jak się nie da oddzielić ciała ludzkiego od ducha, bo będzie martwe, tak „odstawienie Boga” od ludzkiego życia jest receptą na śmierć wieczną. Duch ludzki ma niewyobrażalnie wielką moc podtrzymującą ludzkie ciało przy życiu! Gdy słyszymy, że ktoś „wyzionął ducha”, „oddał ducha”, wiemy, że on skonał. I nie znajduje się on już więcej w gronie żyjących istot na ziemi, lecz jako „martwy” złożony zostaje „w ramiona matki ziemi”. Pełne nadziei są w tej prawdzie o człowieku słowa Jezusa: „Ja zaś wskrzeszę go w dniu ostatecznym” (por. J 11, 25). Jezus może - jak sam o sobie mówi - dać życie! I to wieczne! Tak mówił do Marty, siostry Łazarza, która opłakiwała śmierć swojego brata: „Ja jestem zmartwychwstaniem i życiem. Kto we Mnie wierzy, choćby i umarl, żyć będzie. Każdy, kto żyje i wierzy we Mnie, nie umrze na wieki. Wierzysz w to? (Łk 11, 25-26). Tym, co nas niepokoi w pełnym przyjęciu Jezusowego orędzia o Zbawieniu jest poczucie niestabilności naszej wiary. Wierzymy, ale...! Tłumaczenie się, że jestem wierzący, ale niepraktykujący też i nas samych nie satysfakcjonuje i w pełni nie usprawiedliwia. Gdzieś lawirowanie pomiędzy wiarą i wiedzą jest używaniem rozmagnesowanego kompasu w marszu przez życie po utracie orientacji. Chociaż mocno wyryte są w naszej pamięci katechizmowe prawdy Boże: „Wierzę w Ciebie Boże żywy, w Trójcy Jedyny prawdziwy, wierzę coś objawił Boże, Twe słowo mylić się nie może. Boże choć Cię nie pojmuję, jednak nad wszystko miłują, nad wszystko, co jest stworzone, boś Ty dobro nieskończone", to odczuwa się w chwilach próby i doświadczeń losu zachwianie równowagi i osuwający się grunt pod nogami. Wiara to nie kwestia przyswajania doktryny przez rozum, a więc poznawanie w „ciemności” i widzenie „niewidzialnego”, ale dynamizm życiowy jako zaangażowanie się całej istoty ludzkiej w sprawy Boże ${ }^{61}$. Wiemy i wierzymy, że Bóg niezawodnie przeprowadza swoje plany w świecie, mimo że ten świat jest mocno przesiąknięty grzechem i zbrodnią. Potrzeba prosić Boga o łaskę wiary i jej w nas umocnienie. Wiara jest ryzykownym skokiem w nieznane bez racjonalnego poczucia bezpieczeństwa, nieraz chwilowego zwątpienia, jak tego doświadczył Piotr, który na widok zblizającej

${ }_{61}$ Por. A. Choromański, Osoba ludzka jako „byt relacyjny” - antropologiczne fundamenty eklezjologii Soboru Watykańskiego II, „Studia Teologii Dogmatycznej” 1 (2015), s. 58-87. 
się fali zwątpił i zaczął tonąć. Dobrze, że wiedział do Kogo o ratunek wołać: „Panie, ratuj mnie!” (Mt 14, 30).

„Kto spożywa ten chleb, będzie żył na wieki” $(\mathrm{J} 6,51)$. Głód i pragnienie „kształtują” ludzką egzystencję. Są one prawem biologii ludzkiego ciała. „Jeżeli nie będziecie spożywali Ciała Syna Człowieczego i nie będziecie pili Krwi Jego, nie będziecie mieli życia w sobie" (J 6, 53). Pożywienie jest czymś znaczącym dla człowieka, skoro zmysł smaku decyduje o jego skonsumowaniu lub niespożywaniu go. Walor dobrego odżywiania pomnaża zdolności właściwego funkcjonowania ludzkiego organizmu. Brak strawy staje się odczuwalnym osłabieniem i niewydolnością biologicznych procesów w ciele człowieka. Dlatego zachęca Jezus, aby spożywać to, co znacząco podtrzymuje przy życiu funkcjonowanie istoty ludzkiej. Obrazem mocy zawartej w pożywieniu była dla słuchających Jezusa manna dana Izraelitom na czas ich wyjścia z niewoli egipskiej. Manna spadająca z nieba była strawą na ich zmagania się z codziennym marszem piaskami pustyni. Była zbierana każdego dnia o świcie w ilości odpowiadającej możliwości jej spożycia w ciągu dnia. Zbierali jej tyle, ile mogli zjeść na dzień. A jeśli zebrali jej więcej lub mniej, to sama ulegała proporcjonalnemu „dawkowaniu” do potrzeb konsumpcji każdego na miarę odczuwanego głodu. Tak jak jej nie można było zebrać na zapas, tak też i Eucharystii nie można zebrać na „kilka dni naprzód”. „Chleb żywy” jest darem każdego dnia, który mamy możność przyjmować codziennie w sprawowanej Mszy św. Komunia św. jest pokarmem, który ma swoje korzenie w Słowie Bożym. Nim mamy się umacniać rozważając kierowane do nas przesłanie Boże o Zbawieniu. Pomaga to nam kształtować swoje życie duchowe, które odzywa się tęsknotą za jednością stworzenia ze Stwórcą. Ten, kto żyje Eucharystią, „trwa w Bogu i Bóg trwa w nim". Życie bez Chrystusa ulega szybkiemu wyjałowieniu, staje się „spleśniałe”, traci smak i walor „świeżości”. I tak jak głód i pragnienie „budzą” nas do przyjęcia pożywienia i posilenia swego organizmu, tak i duchowy głód i pragnienie duszy skłaniają nas do szukania pokarmu „chleba żywego" i ,wody żywej”. „Jak łania pragnie wody ze strumieni, tak dusza moja pragnie Ciebie, Boże. Dusza moja Boga pragnie, Boga żywego, kiedy więc przyjdę i ujrzę oblicze Boże?" (Ps 42, 1-2).

Chrystus daje nam siebie podczas Eucharystii, karmi nas tym, co ma znamiona życia wiecznego. Bo rzeczywiście posilamy się Ciałem Pańskim, Ciałem Boga żywego i wiecznego. Przyjmujemy Go swoim ciałem, które ulegnie rozkładowi w prawie śmierci. To ukazuje nam, że Jezus chce nasze życie w wymiarach ziemskiego czasu i przestrzeni przemieniać w tęsknotę za życiem w wieczności. Eucharystia ma w sobie ten dar promieniujący trwaniem w strukturach odwiecznego zamysłu Bożego Zbawienia. Pragnienie przyjmowania Najświętszego Ciała i Krwi Pańskiej odkrywa horyzont wnikania w sferę Bożego życia, 
które jedynie odwiecznie trwa. By to zobaczyć, prośmy Jezusa o dar wzroku, by Go rozpoznać przy łamaniu chleba. Przeżyli to już Apostołowie zmierzający do Emaus. Szli w drodze z Nieznajomym, który im Pisma wyjaśniał, lecz „ich oczy były niejako na uwięzi" (Łk 24, 16). Dopiero przy wieczerzy, podczas modlitwy i łamaniu chleba „otworzyły się im oczy” i rozpoznali swego Mistrza (Łk 24, 31). To niech nas podprowadza do świątyń, gdzie celebracja Mszy św. jest takim spotkaniem z Chrystusem przy stole Słowa Bożego i Eucharystii. Ileż było przyjętych Eucharystii w naszym życiu? Zawsze było to naznaczone trudem bycia godnym jej przyjęcia. By być w stanie łaski uświęcającej, by być wolnym od grzechów, najbardziej chyba nas „męczyło” w podejmowaniu zmagań z naporem zła, w wytrwaniu w podejmowanych postanowieniach poprawy.

Słowa kluczowe: życie, wiara, Bóg, człowiek, Kościół, Zbawienie.

\section{Bibliografia:}

1. Bedouelle G., Szczęśliwi zaproszeni na Ucztę Baranka, „Communio” 1 (1986), s. 9-15.

2. Bellon C., Die Eucharistie ist mehr, viel mehr, „Communio e Communicazione” 21 (2000).

3. Choromański A., Osoba ludzka jako „byt relacyjny” - antropologiczne fundamenty eklezjologii Soboru Watykańskiego II, „Studia Teologii Dogmatycznej” 1 (2015), s. 58-87.

4. Chyła J., Jezus Chrystus Jana Pawła II, Pelplin 2007.

5. Coda P., Hennecke Ch., La fede, evento e promessa, Roma 2000.

6. Dziuba A., Dynamika wiary, Częstochowa 1997.

7. Ewertowski S., Transcendencja ludzkiej osoby, [w:] Veritas Christi liberat, (red.) P. Rabczyński, Olsztyn 2014, s. 187-202.

8. Franciszek, Posynodalna adhortacja apostolska "Christus vivit” do mtodych i calego Ludu Bożego, Poznań 2019.

9. Franciszek, Prawda jest spotkaniem, Kraków 2019.

10. Gagliardi M., La Verità è sintetica, Teologia dogmatica cattolica, Roma 2017.

11. Guggenheim A., Les preuves de l'existence de Dieu, Paris 2008.

12. Guitton J., Tajemnica „rzeczywistej obecności” Chrystusa w Eucharystii, „Communio” 1 (1986), s. 83-88.

13. Guzowski J., Pawet VI o budowaniu cywilizacji mitości, „Studia Elbląskie” XXI (2020), s. 309-322.

14. Jan Paweł II, Przemówienie na audiencji generalnej „Mitość Boga czeka na odpowiedź czlowieka" z 13.II.2002, OsRomPol 4 (2002), s. 13.

15. Jan Paweł II, Przemówienie na audiencji generalnej „«Poszukiwany» przez Boga, czlowiek «szuka» Boga" z 5.VII.2000, OsRomPol 1 (2001), s. 34-35.

16. Jan Paweł II, W Imię Trójcy Przenajświętszej, Città del Vaticano 2002.

17. Jan Paweł II, Wierze w Jezusa Chrystusa Odkupiciela, Città del Vaticano 1989. 
18. Jan Paweł II, Wierze w Kościót, Città del Vaticano 1996.

19. Johannes Paul II, Der Heilige Geist, St. Ottilien 1993.

20. Kijas Z., Czy wiesz, że modlitwa..., Katowice 2020.

21. Kot A., Emergenza sanitaria/Covid-19/. Una sfida per la società civile e pastorale ecclesiale, „Studia Elbląskie” XXI (2020), s. 335-353.

22. Lepa A., Świat manipulacji, Częstochowa 2011.

23. Messori V., Il a souffert sous Ponce Pilate, Paris 2002.

24. Natoli S., Dio è le rivelare, „Filosofia e Teologia” 3 (1996), s. 532-543.

25. Neumann J., Idea zbawcza Królestwa Bożego, Warszawa 2000.

26. Neumann J., Kościót trzeciego tysiąclecia, Warszawa 2006.

27. Neumann J., Tendencje sekularystyczne we wspótczesnej teologii, [w:] Kontrchrześcijaństwo, (red.) A. Sokołowski, Pieniężno 2009, s. 31-41.

28. Neumann J., W nurcie wyzwań ludzkiego życia, [w:] Cztowiek istota (po)znana, Antropologia teologiczna wobec potrzeb i wyzwań wspótczesności, (red.) A. Proniewski, Białystok 2015, t. I, s. 172-182.

29. Paoletti J., L homme entre science et foi, Paris 2007.

30. Ratzinger J., Eschatologia - śmierć $i$ życie wieczne, Poznań 1984.

31. Ratzinger J., Ostatnia Wieczerza, a Eucharystia Kościoła, „Communio” 1 (1986), s. $162-174$.

32. Ratzinger J., Voici quel est notre Dieu, Paris 2001.

33. Ratzinger J.- Benoît XVI, Jésus de Nazareth. De l’entrèe à Jèrusalem à la Rèsurrection, Città del Vaticano 2011.

34. Rey B., Jesus, l' aujourd 'hui de Dieu, Paris 1994.

35. Rey B., Jésus-Christ chemin de notre foi, Paris 1991.

36. Rey B., La Discretion de Dieu, Paris 1997.

37. Rey B., Marcher vers Toi, mon Dieu, Paris 2004.

38. Rey B., Pour des célébrations pénitentielles dans l’esprit de Vatican II, Paris 1995.

39. Rey B., Vivre avant et après la mort, Paris 2001.

40. Sienkiewicz E., Osoba ludzka w kontekście encykliki Benedykta XVI „Deus caritas est”, „Studia Koszalińsko-Kołobrzeskie” 13 (2008), s. 265-293.

41. Tischner J., Myślenie wedlug wartości, Kraków 1982.

42. Troska J., Cztowiek w nauczaniu Jana Pawta II, [w:] In persona Christi, (red.) K. Góźdź, Lublin 2009, t. I. 